OPEN ACCESS

Edited by:

Xunbin Wei,

Peking University, China

Reviewed by:

Lai Wen,

La Jolla Institute for Immunology (LJI),

United States

Clive P. Page,

King's College London,

United Kingdom

Donald H. Maurice,

Queen's University, Canada

Martina Schmidt.

University of Groningen, Netherlands

*Correspondence:

Stefan Brocke

sbrocke@uchc.edu

Specialty section:

This article was submitted to

Cell Adhesion and Migration,

a section of the journal

Frontiers in Cell and Developmental

Biology

Received: 02 December 2020

Accepted: 29 March 2021

Published: 16 April 2021

Citation:

Epstein PM, Basole C and Brocke S (2021) The Role of PDE8 in T Cell Recruitment and Function

in Inflammation.

Front. Cell Dev. Biol. 9:636778.

doi: 10.3389/fcell.2021.636778

\section{The Role of PDE8 in T Cell Recruitment and Function in Inflammation}

\author{
Paul M. Epstein ${ }^{1}$, Chaitali Basole ${ }^{2}$ and Stefan Brocke2* \\ ${ }^{1}$ Department of Cell Biology, UConn Health, Farmington, CT, United States, ${ }^{2}$ Department of Immunology, UConn Health, \\ Farmington, CT, United States
}

Inhibitors targeting cyclic nucleotide phosphodiesterases (PDEs) expressed in leukocytes have entered clinical practice to treat inflammatory disorders, with three PDE4 inhibitors currently in clinical use as therapeutics for psoriasis, psoriatic arthritis, atopic dermatitis and chronic obstructive pulmonary disease. In contrast, the PDE8 family that is upregulated in pro-inflammatory $T$ cells is a largely unexplored therapeutic target. It was shown that PDE8A plays a major role in controlling T cell and breast cancer cell motility, including adhesion to endothelial cells under physiological shear stress and chemotaxis. This is a unique function of PDE8 not shared by PDE4, another CAMP specific PDE, employed, as noted, as an anti-inflammatory therapeutic. Additionally, a regulatory role was shown for the PDE8A-rapidly accelerated fibrosarcoma (Raf)1 kinase signaling complex in myelin antigen reactive $\mathrm{CD} 4^{+}$effector $\mathrm{T}$ cell adhesion and locomotion by a mechanism differing from that of PDE4. The PDE8A-Raf-1 kinase signaling complex affects T cell motility, at least in part, via regulating the LFA-1 integrin mediated adhesion to ICAM-1. The findings that PDE8A and its isoforms are expressed at higher levels in naive and myelin oligodendrocyte glycoprotein (MOG) $35-55$ activated effector $\mathrm{T}$ (Teff) cells compared to regulatory $\mathrm{T}$ (Treg) cells and that PDE8 inhibition specifically affects $\mathrm{MOG}_{35-55}$ activated Teff cell adhesion, indicates that PDE8A could represent a new beneficial target expressed in pathogenic Teff cells in CNS inflammation. The implications of this work for targeting PDE8 in inflammation will be discussed in this review.

Keywords: cAMP, phosphodiesterase, PDE8, Raf-1 kinase, T cell motility, leukocyte recruitment, inflammation, integrin adhesion

\section{INTRODUCTION}

With over 800 members identified in humans, G protein coupled receptors (GPCRs) constitute a large group of signaling molecules expressed on many cells. Together with their other associated signaling molecules, they are the targets for nearly 35\% of approved therapeutics (Sriram and Insel, 2018). The majority of therapeutically targeted GPCRs affect the cAMP signaling pathway which is also a major target of potent anti-inflammatory drugs (Schett et al., 2010; Rabe, 2011; Tenor et al., 2011; De Souza et al., 2012; Milara et al., 2012; Schafer, 2012; Wittmann and Helliwell, 2013; Victoni et al., 2014; Dong et al., 2016; Jarnagin et al., 2016; Tom et al., 2016; Zane et al., 2016a,b; Sriram and Insel, 2018; Blokland et al., 2019). cAMP is involved in many physiological 
functions and a well-established key regulator of chemotaxis and inflammation (Bourne et al., 1974; Amarandi et al., 2016). Binding of extracellular ligands such as chemokines to Gscoupled GPCRs leads to cAMP synthesis via activation of adenylyl cyclase and conversion of ATP to cAMP (Weis and Kobilka, 2018). Additionally, T cell activation leads to a temporary upregulation of cAMP which is then degraded by cyclic nucleotide phosphodiesterase (PDE) enzymes (Wang et al., 1978). PDEs constitute the sole group of molecules known to hydrolyze cAMP and hence maintain spatial and temporal control over cAMP gradients within a cell (Baillie, 2009). PDEs are grouped into 11 different gene families considering their action on CAMP or cGMP, structural similarity and mode of regulation (Lerner and Epstein, 2006). While PDEs had been considered early as good targets for anti-inflammatory drugs, bringing specific PDE inhibitors into clinical use has faced decades of challenges (Francis et al., 2011), mostly because of off target effects including emesis (Giembycz, 2000; Beavo et al., 2007). The approval of small molecule inhibitors of PDE4 to treat major immunologic conditions demonstrates a tremendous progress over the last 7 years with indications expanding at an almost yearly pace (Maurice et al., 2014; Baillie et al., 2019). Current clinical practice includes several small molecule compounds that target PDE4 for the therapy of lung disease (COPD) (Hatzelmann et al., 2010; Weis and Kobilka, 2018), psoriatic arthritis and plaque psoriasis (Schett et al., 2012) and topically for atopic dermatitis (Callender et al., 2019). Hence PDE inhibitors are proving to be of great clinical benefit in inflammatory disorders (Ahmad et al., 2015). This review will focus on the selective and shared roles of PDE isoforms during the regulation of $\mathrm{T}$ cell motility with emphasis on novel insights of PDE8 functions.

\section{PDE EXPRESSION IN IMMUNE CELLS}

As shown in Table $\mathbf{1}$ [adapted from Lerner and Epstein (2006)], PDEs are encoded by twenty one genes and are by convention organized into 11 gene families based on their key properties. These include overlap in sequence, specificity for cAMP or cGMP as substrate and their mode of regulation. With alternative splicing as well as the existence of multiple transcription initiation sites, at least 100 different forms of PDE have been cloned and many are expressed in a cell and tissue selective manner. Among the 11 PDE gene families, PDE4, PDE7, and PDE8 selectively hydrolyze cAMP as substrate and degrade it into 5'-AMP, PDE5, PDE6, and PDE9 selectively hydrolyze cGMP as substrate, and PDE1, PDE2, PDE3, PDE10, and PDE11 hydrolyze both cAMP and cGMP as substrate. Of note, the affinity of PDE8 for CAMP is greater than that of any of the other PDE gene families (Fisher et al., 1998a; Hayashi et al., 1998; Soderling et al., 1998a; Gamanuma et al., 2003; Bender and Beavo, 2006).

\section{PDE4}

Early studies showed PDE4 to be the predominant form of PDE expressed in the cytosolic fraction of human lymphocytes
(Epstein and Hachisu, 1984), with PDE4A, 4B, and 4D, but not 4C being expressed (Jiang et al., 1998). PDE4 has long been known to play a key role in regulating $\mathrm{T}$ cell activation and functions (Michie et al., 1996; Ekholm et al., 1997; Erdogan and Houslay, 1997; Gantner et al., 1997a,b; Sommer et al., 1997; Barnette et al., 1998; Jin et al., 1998, 2010; Bielekova et al., 2000; Hatzelmann and Schudt, 2001; Kanda and Watanabe, 2001; Arp et al., 2003; Abrahamsen et al., 2004; Asirvatham et al., 2004; Claveau et al., 2004; Jimenez et al., 2004; Bjorgo and Tasken, 2006; Peter et al., 2007; Bjorgo et al., 2010, 2011; Vang et al., 2016). A key mechanism appears to be the modulation of signal transduction through the T cell receptor (TCR). Activation of the TCR leads to CAMP production localized in lipid rafts, activation of CAMP dependent protein kinase A (PKA) and subsequent inhibition of the TCR signal (Abrahamsen et al., 2004; Bjorgo and Tasken, 2006; Wehbi and Tasken, 2016; Figure 1). However, engagement of the co-stimulatory receptor CD28 leads to the recruitment of beta-arrestin and PDE4 to lipid rafts and the decrease of the local cAMP pool and PKA activity. PDE4 inhibitors downregulate the TCR signal by increasing local cAMP concentrations and PKA activity and counteract the CD28-induced recruitment of PDE4. Thus, localized activities of CAMP, PKA, and PDE4 regulate the upstream TCR signal necessary for $\mathrm{T}$ cell activation and the subsequent initiation of effector functions.

\section{PDE3}

PDE3 was found to be the predominant form expressed in particulate fractions of human lymphocytes, solely as PDE3B (Tenor et al., 1995; Ekholm et al., 1997; Sheth et al., 1997). In contrast, PDE3B expression is low in regulatory $\mathrm{T}(\mathrm{reg})$ cells, and it appears that the low catalytic activity of PDE3B is critical for the regulation of Treg cell-specific gene expression (Gavin et al., 2007). When PDE expression profiles of human T and $\mathrm{B}$ lymphocytes were compared, it is of note that in contrast to T cells, which expressed high amounts of PDE3, B cells expressed little or no PDE3 (Gantner et al., 1998).

\section{PDE7}

PDE7, primarily PDE7A, was also found to be expressed in human lymphocytes, to a lesser extent than PDE3 and PDE4, with PDE7A1 primarily cytosolic and PDE7A2 mainly associated with a particulate fraction (Bloom and Beavo, 1996; Giembycz et al., 1996; Bender and Beavo, 2006). Subsequent studies also showed that PDE1B, PDE7A, and PDE8A were all induced following activation of human lymphocytes (Epstein et al., 1980, 1987; Jiang et al., 1998; Glavas et al., 2001; Kanda and Watanabe, 2001). A critical role of the induction of PDE7 for a full T cell activation has been reported (Li et al., 1999; Guo et al., 2009; Szczypka, 2020). Inhibition studies using PDE7 selective inhibitors have yielded divergent results and seem to point to a context and other PDE isoform dependent role of PDE7 in T cell functions and T cell mediated inflammation (Li et al., 1999; Nakata et al., 2002; Yang et al., 2003; Nueda et al., 2006; Goto et al., 2009; Guo et al., 2009; Kadoshima-Yamaoka et al., 2009; Redondo et al., 2012; Gonzalez-Garcia et al., 2013; Xu et al., 2016; Martin-Alvarez et al., 2017; Szczypka, 2020). 
TABLE 1| Pde gene families.

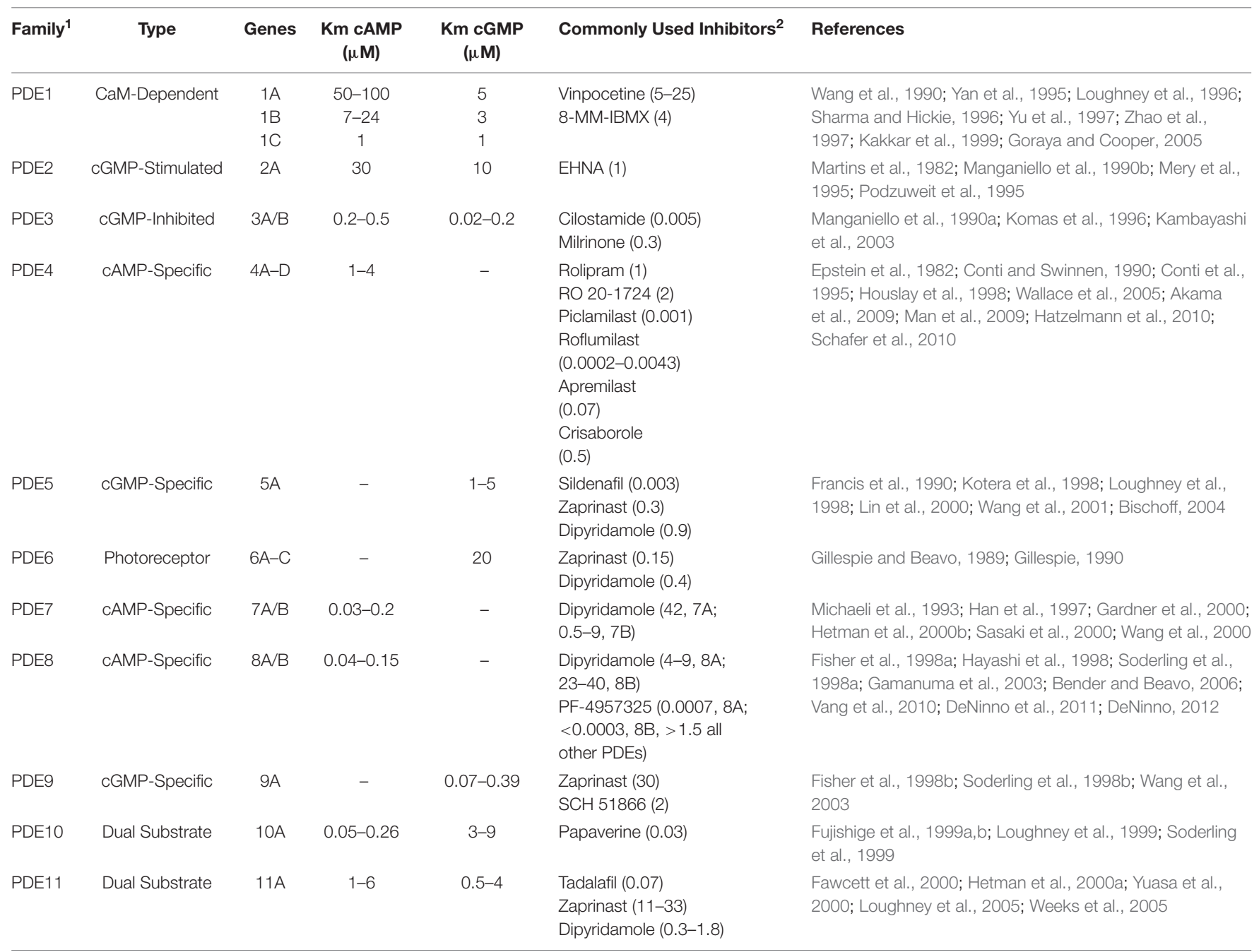

${ }^{1}$ Shown in this table [adapted from Lerner and Epstein (2006)] are the eleven PDE gene families, the known genes within them, their affinity constants for cAMP and cGMP, and commonly used pharmacological inhibitors for each of the families. The substrate affinity constants listed are approximate and where ranges are given, they represent the range of different $K m s$ reported for these family members in the references cited.

${ }^{2}$ The numbers in parentheses are the approximate reported Kis or IC 50 S for inhibition of that PDE gene family, given in $\mu M$. Note: the non-specific methylxanthine inhibitor IBMX inhibits all of the PDE families with the notable exception of the PDE8 and PDE9 gene families, which appear to be resistant to IBMX inhibition.

\section{PDE8}

The expression of PDE8 in immune cells is listed in Table 2. The function of PDE8 in T cells and cancer cells is discussed in detail below.

Additionally, very low levels of PDE1, PDE2, and PDE5 activity were also detected in $\mathrm{CD}^{+}$and $\mathrm{CD}^{+}$human $\mathrm{T}$ cells (Tenor et al., 1995).

\section{Regulatory T(reg) Cells}

As mentioned, PDE3 expression was found to be diminished in Treg cells as compared to $\mathrm{CD}^{+}{ }^{+} \mathrm{T}$ cells (Gavin et al., 2007). Subsequently it was found that gene expression of $P d e 1 B, P d e 2 A$, $P d e 3 B, P d e 4 B, P d e 5 A, P d e 7 A$, and $P d e 8 A$ and protein expression of PDE3B, PDE4B2, and PDE8Awere all reduced in Treg cells as compared to CD4 ${ }^{+}$Teff cells (Bopp et al., 2007, 2009; Vang et al., 2010, 2013; Vaeth et al., 2011; Basole et al., 2017). The low expression levels of PDEs in Treg cells and high level of cAMP have been linked to the mechanism by which Treg cells suppress the function of effector T(eff) cells through the direct cell-to-cell transfer of cAMP (Bopp et al., 2007).

\section{PDE8A BUT NOT PDE4 IS CONTROLLING ACTIVATED T CELL MOTILITY}

Inhibition of PDEs regulates $\mathrm{T}$ cell proliferation, cytokine production and motility (Sommer et al., 1997; Pette et al., 1999; Bielekova et al., 2000; Vang et al., 2010, 2016; Bjorgo et al., 2011; Mosenden and Tasken, 2011; Wehbi and Tasken, 2016; Basole et al., 2017; Figure 1). Only a small number 


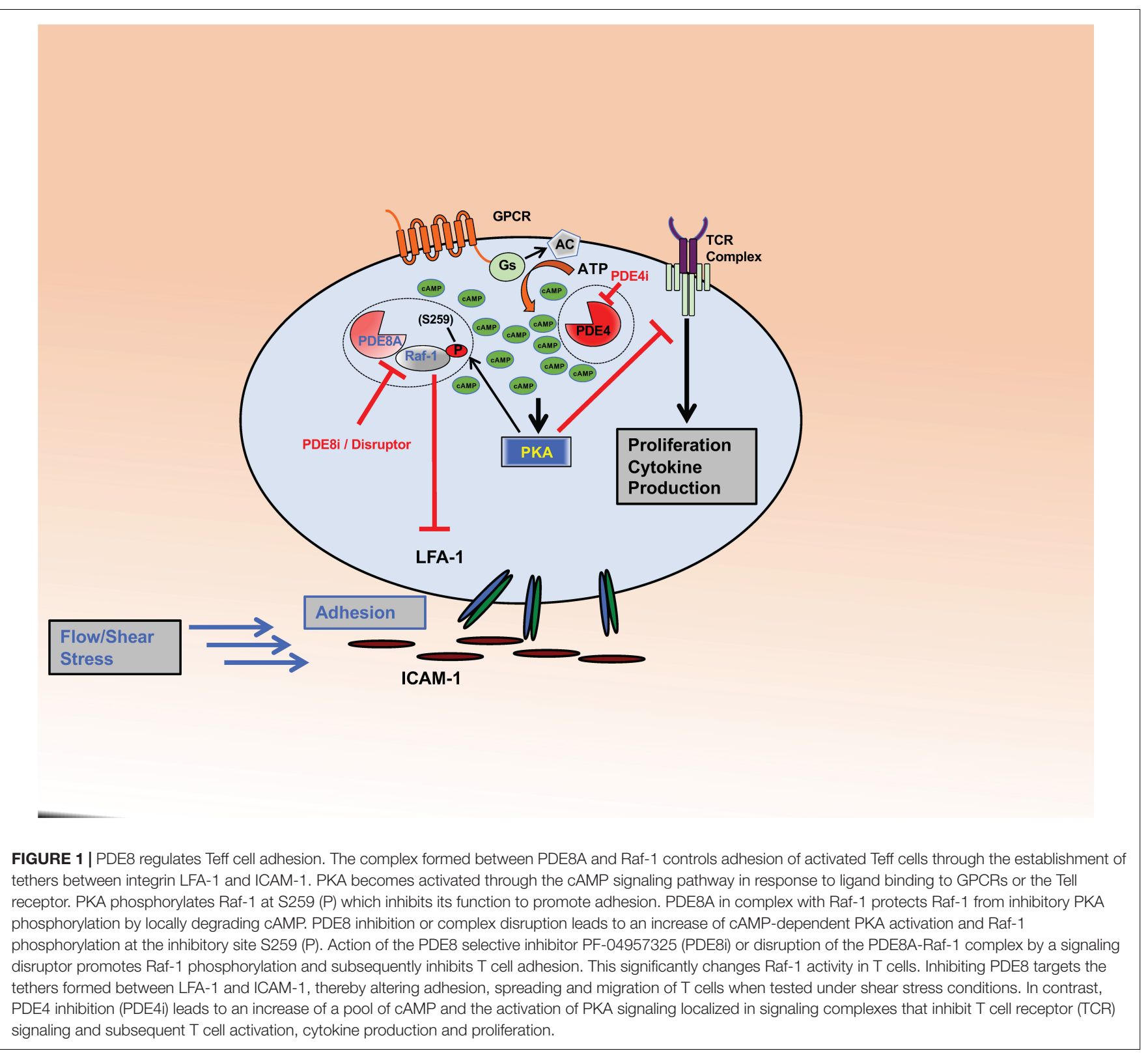

of PDEs are currently targeted by approved therapeutics, and there is a significant knowledge gap about the specific and potentially therapeutic role of other PDE isoforms. This led to the development of novel PDE inhibitors, including those for therapy of inflammatory conditions. Recently, there have been numerous studies on PDE8A and PDE8B, a family of cAMP specific PDEs (Fisher et al., 1998a; Hayashi et al., 1998; Soderling et al., 1998a; Glavas et al., 2001; Kobayashi et al., 2003; Dong et al., 2006, 2010, 2015; Chen et al., 2009; Vang et al., 2010, 2016; DeNinno et al., 2011; Tsai and Beavo, 2012; Brown et al., 2013; Demirbas et al., 2013; Maurice, 2013; Shimizu-Albergine et al., 2016; Basole et al., 2017; Johnstone et al., 2017; Kelly, 2018). PDE8A and B are expressed widely in human tissue (Wang et al., 2008) with functions identified in testosterone and corticosteroid production (Tsai et al., 2010; Demirbas et al., 2013), myocyte contraction (Patrucco et al., 2010), lymphocyte adhesion and chemotaxis (Dong et al., 2006, 2015; Vang et al., 2010, 2013; Basole et al., 2017), memory and coordination (Tsai et al., 2012), human airway smooth muscle regulation (Johnstone et al., 2017), strong association with immune protection against intracellular pathogens (Blanco et al., 2017), brain disorders associated with inflammation (Chimienti et al., 2019) and T cells in systemic lupus erythematosus (SLE) (Orlowski et al., 2008). In a recent study, single nucleotide polymorphisms in the $P D E 8$ region were found to be associated with Sjögren's Syndrome (Taylor et al., 2017). T cell activation induces PDE8A1 (Glavas et al., 2001), a PDE isoform with a cAMP affinity up to 100 times higher than PDE4 isoforms (Fisher et al., 1998a; Hayashi et al., 1998; Soderling et al., 1998a; Gamanuma et al., 2003; Bender and Beavo, 2006). This property of the PDE8 family suggests that 
TABLE 2 | PDE8A expression and function in immune cells.

\begin{tabular}{|c|c|c|c|c|}
\hline $\begin{array}{l}\text { Immune cell } \\
\text { subpopulation }\end{array}$ & $\begin{array}{l}\text { PDE gene } \\
\text { expression }\end{array}$ & $\begin{array}{l}\text { PDE protein } \\
\text { expression }\end{array}$ & Results & References \\
\hline CD4 + T cells & PDE8A1 & PDE8A1 & Upregulation of PDE8A1 after polyclonal T cell activation & Glavas et al., 2001 \\
\hline $\begin{array}{l}\text { Mitogen-activated } \\
\text { splenocytes, anti-CD3 } \\
\text { activated CD4 }{ }^{+} T \text { cells }\end{array}$ & PDE8A & & Induction of PDE8A expression in response to stimulus & $\begin{array}{l}\text { Dong et al., 2006; Vang } \\
\text { et al., } 2010\end{array}$ \\
\hline $\begin{array}{l}\text { Antigen exposed naïve and } \\
\text { memory CD4 }{ }^{+} T \text { cells }\end{array}$ & PDE8A & & $\begin{array}{l}\text { Changes in temporal expression patterns in response to } \\
\text { antigen challenge }\end{array}$ & Vang et al., 2010 \\
\hline $\mathrm{CD}^{+}+\mathrm{T}$ cells & PDE8A & PDE8A & $\begin{array}{l}\text { Association of PDE8A expression and accumulation of } \\
\text { sensitized T cells in draining lymph node of in an animal } \\
\text { model of allergic airway disease (AAD) }\end{array}$ & Vang et al., 2016 \\
\hline CD4- T cells & Low PDE8A & Low PDE8A & Control cell population in AAD & Vang et al., 2016 \\
\hline $\mathrm{CD}^{+}{ }^{+} \mathrm{T}$ cells & High PDE8A & High PDE8A & Hilar lymph node in AAD & Vang et al., 2016 \\
\hline $\mathrm{CD}^{+}{ }^{+}$effector $\mathrm{T}(\mathrm{eff})$ cells & $\begin{array}{l}\text { Increased PDE8A } \\
\text { expression after } \\
\text { polyclonal activation }\end{array}$ & $\begin{array}{l}\text { Increased PDE8A } \\
\text { expression after polyclonal } \\
\text { activation }\end{array}$ & $\begin{array}{l}\text { PDE8A inhibition by enzymatic inhibitor or a PDE8A- } \\
\text { Raf-1 kinase complex disruptor decreases Teff cell } \\
\text { adhesion and migration under shear stress conditions }\end{array}$ & Basole et al., 2017 \\
\hline $\begin{array}{l}\text { CD4+ regulatory } \mathrm{T}(\mathrm{reg}) \\
\text { cells }\end{array}$ & $\begin{array}{l}\text { Low PDE8A (and all } \\
\text { other PDEs expressed } \\
\text { in T cells) }\end{array}$ & $\begin{array}{l}\text { Low PDE8A (and all other } \\
\text { PDEs expressed in T cells) }\end{array}$ & High cAMP levels in Treg cells & $\begin{array}{l}\text { Bopp et al., 2009; Vang } \\
\text { et al., 2010; Vang et al., } \\
\text { 2013; Basole et al., } 2017\end{array}$ \\
\hline $\begin{array}{l}\text { T cells in systemic lupus } \\
\text { erythematosus (SLE) }\end{array}$ & PDE8A1 & & $\begin{array}{l}\text { Upregulation of PDE8A1 transcripts in SLE T cells vs. } \\
\text { normal controls }\end{array}$ & Orlowski et al., 2008 \\
\hline Macrophages & PDE8A & & Promotes susceptibility to HIV-1 infection & Booiman et al., 2014 \\
\hline
\end{tabular}

they may regulate changes of baseline cAMP gradients around cell signaling complexes. The availability of PDE8 inhibitors and disruptors (Table 3) greatly enhanced the ability to conduct studies on the function of PDE8 in vitro and in vivo.

It was shown that PDE8A regulates motility of lymphocytes and breast cancer cells, including adhesion to endothelial cells under physiological shear stress and chemotaxis (Dong et al., 2006, 2015; Vang et al., 2010, 2013; Basole et al., 2017). This seems to be a unique feature of PDE8 that is distinct from PDE4 activity (Vang et al., 2016). The therapeutic potency of biologics and compounds interacting with molecular targets on pathogenic $\mathrm{T}$ cells has been shown in vitro and in vivo (Yednock et al., 1992; Brocke et al., 1999; Steinman, 2005; Healy and Antel, 2016). Current observations demonstrate PDE8 to be one of those targets for blocking Teff cell motility and potentially

TABLE 3 | Broad and selective PDE8 inhibitors.

\begin{tabular}{|c|c|}
\hline Inhibitor, selectivity & References \\
\hline PF-4957325, PDE8A/B & $\begin{array}{l}\text { Vang et al., 2010; DeNinno } \\
\text { et al., 2011; DeNinno, } 2012\end{array}$ \\
\hline BC8-15, Dual PDE4/8 & Demirbas et al., 2013 \\
\hline Dual PDE7/8 & Jankowska et al., 2017 \\
\hline Multiple PDE8 inhibiting compounds & $\begin{array}{l}\text { Vang et al., 2010; DeNinno } \\
\text { et al., 2011; DeNinno, } 2012\end{array}$ \\
\hline Dipyridamole, PDE 4-8, 10, and 11 & Lerner and Epstein, 2006 \\
\hline Multiple 2-chloroadenine derivatives, PDE8A & Huang et al., 2020 \\
\hline Cell-penetrating peptide agent (PPL-008) & Blair et al., 2019 \\
\hline
\end{tabular}

\section{inhibiting the PDE8A-C-Raf complex}

Stearylated cell-permeable peptide disrupting Brown et al., 2013

the Raf-1-PDE8A Complex based on the

Raf-1-docking sequence from PDE8A,

encompassing residues R454-T465 inflammation (Dong et al., 2006, 2015; Vang et al., 2010, 2013, 2016; Basole et al., 2017). The potential role of PDE8 in models of inflammation and cancer is summarized in Table 4.

\section{DIFFERENTIAL ROLES OF PDES IN T CELL ADHESION}

Previous studies on the role of PDE8 were done using the prototypic chemokine CXCL12 which is known to induce migration of leukocytes, including murine splenocytes (Cinamon et al., 2001). As measured in a transwell assay system CXCL12 stimulates equally the migration of mouse splenocytes, both unstimulated and stimulated with the mitogen concanavalin A (Con A). Interestingly, when probing the cAMP signaling pathway in CXCL12-induced chemotaxis, differential effects were observed on directed leukocyte migration between exposure of cells to a cell permeable cAMP analog vs. stimulation of adenylyl cyclase or inhibition of PDE. While CXCL12 dependent chemotaxis of both naïve and mitogen activated splenocytes was inhibited by direct exposure to dibutyryl cAMP, activated cells were resistant to indirect CAMP regulation through stimulation of adenylyl cyclase or PDE inhibition (Dong et al., 2006). Activation of adenylyl cyclase through Forskolin (Fsk) or PDE inhibition through the broad PDE enzymatic inhibitor IBMX, significantly reduced CXCL12-induced migration of naive but not activated splenocytes. Additionally, chemotaxis of mitogen-activated splenocytes was not inhibited by PDE3-, PDE4-, and PDE7-selective inhibitors. It is important to note that IBMX is a pan-cAMP specific PDE inhibitor that inhibits all known cAMP PDEs with the exception of PDE8 (Soderling et al., 1998a; Soderling and Beavo, 2000). In contrast, dipyridamole (DP), a broad PDE inhibitor that also targets 
TABLE 4 | PDE8 in models of inflammation and cancer.

\begin{tabular}{|c|c|c|}
\hline PDE8 isoform/assay & Model and Function & References \\
\hline PDE8A/Expression study & $\begin{array}{l}\text { Temporal changes of PDE8A expression in } \mathrm{CD}^{+} \mathrm{T} \text { cell specific for a cytochrome } \mathrm{C} \\
\text { peptide/l-E }{ }^{k} \text { antigen complex transferred into wildtype (non-transgenic) mice, activated } \\
\text { with antigen in vivo. }\end{array}$ & Vang et al., 2010 \\
\hline PDE8A/Expression study & $\begin{array}{l}\mathrm{CD}^{+} \text {and } \mathrm{CD}^{-}{ }^{-} \mathrm{T} \text { cell populations in a model of ovalbumin-induced allergic airway } \\
\text { disease in mice }\end{array}$ & Vang et al., 2016 \\
\hline PDE8 inhibition study ex vivo and in vitro & T cells responding to myelin oligodendrocyte glycoprotein (MOG)peptide $\mathrm{MOG}_{35-55}{ }^{1}$ & Vang et al., 2016 \\
\hline PDE8A1/PDE8A2 Expression study & In vivo $\mathrm{MOG}_{35-55}$ activated $\mathrm{CD} 4^{+} \mathrm{CD}_{25}{ }^{-}$effector and $\mathrm{CD} 4^{+} \mathrm{CD} 25^{+}$regulatory cells ${ }^{1}$ & Basole et al., 2017 \\
\hline $\begin{array}{l}\text { PDE8A and B/ Regulating } T \text { cell adhesion } \\
\text { through inhibitor and peptide disruptor study }\end{array}$ & In vivo $\mathrm{MOG}_{35-55}$ activated $\mathrm{CD} 4^{+} \mathrm{CD} 5^{-}$effector and $\mathrm{CD} 4^{+} \mathrm{CD} 25^{+}$regulatory $\mathrm{T}$ cells ${ }^{1}$ & Basole et al., 2017 \\
\hline $\begin{array}{l}\text { PDE } 4-8,10 \text {, and } 11 / \text { Use of broad PDE } \\
\text { inhibitor dipyridamole in vivo treatment }\end{array}$ & Treatment of experimental autoimmune encephalomyelitis ${ }^{2}$ & Sloka et al., 2013 \\
\hline $\begin{array}{l}\text { PDE8A-C-Raf complex/PDE8A-C-Raf } \\
\text { complex disruptor PPL-008 }\end{array}$ & $\begin{array}{l}\text { Treatment of human malignant MM415 melanoma cell line in vitro and a MM415 } \\
\text { melanoma xenograft mouse model in vivo with cell-penetrating PDE8A-C-Raf complex } \\
\text { disruptor peptide agent (PPL-008) leads to reduced phospho-ERK signaling and } \\
\text { growth inhibition }\end{array}$ & $\begin{array}{l}\text { Blair and Baillie, } 2019 \\
\text { Blair et al., } 2019\end{array}$ \\
\hline PDE8A and B/Expression study & $\begin{array}{l}\text { Human breast adenocarcinoma estrogen receptor-positive MCF-7 and T-47D cell lines } \\
\text { Human breast adenocarcinoma estrogen receptor-negative MDA-MB-123 MB-231 and } \\
\text { MDA-MB-435 cell lines }\end{array}$ & Dong et al., 2015 \\
\hline PDE8A and B, Expression study & Human breast cancer patient biopsies and tissue arrays & Dong et al., 2015 \\
\hline PDE8A and B, Inhibitor study & Inhibition of MDA-MB-231 breast cancer cell migration and wound healing & Dong et al., 2015 \\
\hline $\begin{array}{l}\text { PDE } 4-8,10 \text {, and } 11 / \text { Use of the broad PDE } \\
\text { inhibitor dipyridamole in vivo treatment }\end{array}$ & Prevention of triple-negative breast-cancer progression in a mouse model & $\begin{array}{l}\text { Virgilio et al., 2012; } \\
\text { Spano et al., } 2013\end{array}$ \\
\hline $\begin{array}{l}\text { PDE } 4-8,10 \text {, and } 11 / \text { Use of the broad PDE } \\
\text { inhibitor dipyridamole in vivo treatment }\end{array}$ & $\begin{array}{l}\text { Delay of breast cancer lesion onset, tumor progression and suppression of lung } \\
\text { metastasis in a mouse model }\end{array}$ & Wang et al., 2013b \\
\hline
\end{tabular}

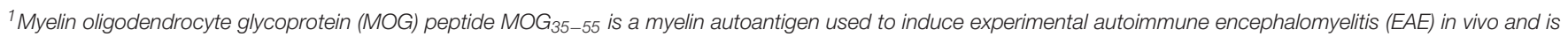
recognized by $T$ and $B$ cells in multiple sclerosis (MS).

${ }^{2}$ Experimental autoimmune encephalomyelitis (EAE) is an autoimmune disease model for multiple sclerosis (MS).

PDE8 (Soderling et al., 1998a), was found to inhibit migration of naïve and activated splenocytes in response to CXCL12 (Dong et al., 2006). Addition of Fsk in combination with DP increased inhibition of chemotaxis of both naïve and activated splenocytes.

Of note, Rp-cAMPS, an inhibitor of PKA, reversed the DP mediated inhibition of splenocyte migration when exposed to CXCL12. DP is also known to inhibit nucleoside transporters, thereby increasing extracellular adenosine which causes increased levels of cAMP in T cells (Wang et al., 2013a). However, in these assays the action of DP on motility was unaffected by extracellular adenosine deaminase, suggesting that the effect of DP is independent of a possible increase in extracellular adenosine. Expression studies of splenocyte and T cell mRNA demonstrated upregulation of PDE4B2, PDE7A1 and $\mathrm{A} 3$, and PDE8A1 in response to $\mathrm{T}$ cell activation (Glavas et al., 2001; Dong et al., 2006; Vang et al., 2010). The results indicate that PDE8A1 may have a critical function in regulating cAMP pools that control T cell motility (Dong et al., 2006).

\section{PDE8A EXPRESSION IN EFFECTOR T (Teff) CELLS IN VIVO}

PDE8 expression was not only seen in unactivated and polyclonally stimulated splenocytes and $\mathrm{CD}^{+} \mathrm{T}$ cells in vitro, but also in highly purified $\mathrm{CD} 4^{+} \mathrm{T}$ cell populations in vivo. In a widely used TCR transgenic mouse model to investigate highly purified $\mathrm{T}$ cell populations in vivo in the absence of other leukocytes (Ben-Sasson et al., 2009, 2013), it was shown that antigenic activation resulted in PDE3, 4, and 8 expression in the transgenic T cell subset. Expression levels of the PDE8A gene in activated $\mathrm{CD} 4^{+} \mathrm{T}$ cells were up to fifty percent of those of the PDE3B and PDE4B genes (Vang et al., 2010).

\section{SELECTIVE INHIBITION OF PDE8 BLOCKS SPLENOCYTE ADHESION}

Integrins including $\alpha \mathrm{L}$ or $\alpha 4$ chains have been shown to promote firm adhesion to endothelial cell ligands. cAMP is known to regulate expression and activation of integrin molecules on lymphocytes and other leukocyte populations.

As mentioned, DP was found to inhibit PDE8 and leukocyte migration. Incubation with DP led to a significant reduction of the proportion of $\alpha \mathrm{L}^{h i}$ and $\alpha 4^{h i}$ Teff cells.

In contrast, IBMX did not significantly reduce integrin surface expression. Similarly, DP reduced the proportion of activated splenocytes to endothelial cells while IBMX did not have the same effect (Vang et al., 2010). Of note, the potent PDE4 inhibitor piclamilast (PICL) and the PDE3 inhibitor motapizone also did not suppress adhesion. Further, no significant effect of the canonical PDE4 inhibitor rolipram was reported when the interactions between activated $\mathrm{T}$ cells and immobilized VCAM1 or endothelial cells were tested. The specific role of PDE8 action in T cell adhesion could be confirmed using PF-4957325, a selective PDE inhibitor with $\mathrm{IC}_{50}$ for PDE8A $=0.0007 \mu \mathrm{M}$ 
and $\mathrm{IC}_{50}$ for $\mathrm{PDE} 8 \mathrm{~B}<0.0003 \mu \mathrm{M}$, and with $\mathrm{IC}_{50}$ for all other PDEs > $1.5 \mu \mathrm{M}$ (Vang et al., 2010; DeNinno et al., 2011; DeNinno, 2012; Tables 1, 3). As with DP, PF-4957325 significantly suppressed $\mathrm{T}$ cell blast adhesion to endothelial cells. Interestingly, when tested in $\mathrm{T}$ cell proliferation in response to anti-CD3 stimulation, PICL was significantly more potent at inhibiting $\mathrm{T}$ cell proliferation in comparison to PF-4957325 at identical concentrations. These data suggest a specific role for PDE8 in regulating Teff cell adhesion to endothelial cells. Subsequently, it was shown that cAMP signaling controls adhesion in these assays which could account for the effect of PDE8 inhibition.

One of the mechanisms by which cAMP regulates $\mathrm{T}$ cell adhesion is through the action of PKA which regulates cell surface expression and affinity of integrin molecules and phosphorylates $\alpha 4$ integrin involved in cellular adhesion (Goldfinger et al., 2003; Lim et al., 2007; Chilcoat et al., 2008). Thus, dibutyryl-cAMP, acting through PKA, inhibits $\mathrm{T}$ cell adhesion to endothelial cell ligands. The effect of increased cAMP levels on cell adhesion was not reversed by CXCL12 (Vang et al., 2010).

\section{ENDOTHELIAL CELLS ALSO EXPRESS PDE8A}

Cells of the murine brain endothelium-derived cell line bEnd.3, a polyoma virus middle $\mathrm{T}$ oncogene expressing endothelioma cell line (Montesano et al., 1990; Takeuchi and Baichwal, 1995) used for in vitro adhesion studies (Vang et al., 2010, 2016; Basole et al., 2017), have been shown to express PDE1, 2, 3, 4, 5, and 7 (Ashikaga et al., 1997; Netherton and Maurice, 2005). Additionally, bEnd. 3 cells express PDE8A at levels that are about 25 percent of $\mathrm{PDE} 4 \mathrm{~B}$, which is comparable to expression of PDE2A, a functionally critical isoform in endothelial cells (Vang et al., 2010). DP did not induce PDE8A in bEnd.3 or T cells. These results are in contrast to PDE4B which was significantly upregulated in both of these cell populations in response to the increase in intracellular cAMP. These differential responses of PDEs to CAMP signaling further point to different and nonoverlapping roles of PDE8 and other PDE isoforms within the same cell populations (Vang et al., 2010).

\section{PDE8A GENE EXPRESSION IN CD4 ${ }^{+}$ CD25 $^{+}$REGULATORY T (Treg) CELLS}

It is well established that Teff cells and Treg cells express significantly different levels of PDEs. The transcription factor forkhead box P3 (Foxp3) expressed in Treg cells has been shown to selectively repress genes, including $P D E$ genes, leading to elevated levels of intracellular cAMP (Bopp et al., 2007, 2009; Vaeth et al., 2011).

Remarkably, the Treg cell subsets show significantly lower expression for Pde1a, Pde1b, Pde2a, Pde 3b, Pde 4b, Pde5a, Pde7a, and $P d e 8 a$ genes compared to naive Teff cell subsets. In addition to lower expression of $\mathrm{PDE} 3 \mathrm{~B}$ and $\mathrm{PDE} 4 \mathrm{~B} 2$, $\mathrm{T}$ reg cells express significantly lower levels of PDE8A in comparison to Teff cells
(Vang et al., 2013). Consistent with these findings, it was shown that Foxp3 represses PDE3B, while reduced PDE3B expression through genetic means permits normal Treg cell homeostasis and Treg cell-specific gene expression (Gavin et al., 2007). In contrast, Treg and Teff cells express comparable levels of PDE4B3, PDE4D, and PDE7A (Vang et al., 2013). While the regulation of select PDE isoforms including PDE8 through Foxp3 in Treg cells is well established, the exact role of PDE isoforms regulating Treg cell function remains to be elucidated.

\section{CD4 ${ }^{+}$T CELLS SELECTIVELY EXPRESS PDE8A IN INFLAMMATORY DISEASE}

PDE8A but not PDE8B has been shown to be expressed in T cells (Hayashi et al., 1998, 2002; Dong et al., 2006, 2010).

To test the potential of PDE8 as a target to treat inflammation in vivo, the expression of PDE8 was determined in draining lymph nodes of mice that were immunized with ovalbumin (OVA) in an allergic airway disease (AAD) model (Vang et al., 2016).

In this mouse model of $\mathrm{AAD}$, clinical and pathologic resolution occurs with long-term exposure to OVA aerosol. $\mathrm{T}$ cells accumulate in hilar and inguinal lymph nodes that drain the exposed lung tissue. The expression of PDE8A protein was determined by Western immunoblot in the $\mathrm{CD}^{+} \mathrm{T}$ cell population that was isolated from the lymph nodes at various time points after the induction of AAD. It was found that PDE8A was significantly higher in the $\mathrm{CD} 4^{+}$population as compared to the $\mathrm{CD}^{-}$lymph node populations. Importantly, the increased PDE8A expression was only seen in in vivo activated CD $4^{+} \mathrm{T}$ cell populations, i.e., after antigen exposure, but not in $\mathrm{CD}^{+}{ }^{+} \mathrm{T}$ cells from naïve lymph nodes.

Taken together, these results demonstrate that PDE8A expression is higher in the hilar $\mathrm{CD}^{+}$lymph node cell population than in the hilar $\mathrm{CD}^{-}$lymph node cell population at various stages of AAD. Additionally, expression levels of the $P d e 8 a$ gene were higher during the acute AAD phase than the late stage tolerance stage of the disease model (Vang et al., 2016).

\section{PDE8 AND PDE4 INHIBITION SHOW DIFFERENTIAL EFFECTS ON THE IN VITRO ADHESION OF T CELLS TO ENDOTHELIAL CELLS}

Studies including a combination of selective and broad PDE inhibitors established overlapping and distinct effects of PDEs in T cell adhesion. Specifically, only the use of PDE inhibitors that target PDE8, including the broad PDE8 inhibitor DP and the highly PDE8-selective inhibitor PF-04957325 (Vang et al., 2010), demonstrated significant inhibition of splenocyte and $T$ cell adhesion. Of note, the PDE inhibitor IBMX, which inhibits all known PDEs that hydrolyze cAMP with the exception of PDE8, shows little inhibitory effect when tested in assays measuring $\mathrm{T}$ cell adhesion to endothelial cells. Surprisingly, the potent PDE4 inhibitor PICL showed opposite effects both when used 
alone or in combination with a PDE8 inhibitor by enhancing adhesion of $\mathrm{T}$ cells to endothelial cells. Taken together, these studies show that PDE4 and PDE8 inhibitors exert opposite effects on $\mathrm{T}$ cell-endothelial cell interactions in adhesion assays (Vang et al., 2016).

\section{OPPOSING EFFECTS OF PDE8 AND PDE4 INHIBITORS ON PROLIFERATION OF ANTIGEN OR ANTI-CD3 STIMULATED T CELLS}

In contrast to the observations in adhesion assays, $\mathrm{T}$ cell proliferation could be significantly inhibited by the PDE4 inhibitor PICL while the PDE8 inhibitor PF-04957325 showed little effect on proliferation in these studies (Vang et al., 2016). This indicates an action of PDE8 inhibitors on $T$ cell adhesion that is independent of the well-documented inhibition of mitogen-activated protein kinase (MAP) kinase signaling by PDE inhibitors (Giembycz et al., 1996; Essayan et al., 1997; Bjorgo et al., 2011). T cells that were stimulated by specific antigen or anti-CD3 in vitro responded significantly lower in proliferation assays when exposed to PICL in comparison to exposure of equal doses of PF-04957325. Importantly, the opposing effects that were seen in adhesion assays were not seen in proliferation assays since combining PICL and PF-04957325 led to a small increase in suppression of proliferation (Vang et al., 2016). These results clearly demonstrate differential actions of PDE4 and PDE8 in regulating key $\mathrm{T}$ cell functions.

\section{REGULATION OF VASCULAR ADHESION OF Teff CELLS VS. Treg CELLS THROUGH INHIBITION OF PDE8 UNDER PHYSIOLOGIC SHEAR STRESS}

It was found that Treg cells form significantly stronger tethers to endothelial cells compared to Teff cells (Maganto-Garcia et al., 2011). It was also established that PDE8A expression in Teff cells differed significantly from that in Treg cells (Vang et al., 2013). Based on these observations adhesion and migration of Teff and Treg cells were investigated for the effects of PDE8 inhibition on these processes (Basole et al., 2017). This question was addressed in a mouse model of autoimmune disease using encephalitogenic Teff cell populations mediating experimental autoimmune encephalomyelitis (EAE). T cells were isolated from draining lymph nodes of mice immunized with a myelin derived peptide, myelin oligodendrocyte glycoprotein $(\mathrm{MOG})_{35-55}$, an antigen that is used to induce EAE in susceptible strains of mice (Brocke et al., 1996; Biton et al., 2011). PDE8A1 and PDE8A2 expression at the protein level was compared in the fraction of $\mathrm{CD} 4{ }^{+} \mathrm{CD} 25^{-}$Teff cells and $\mathrm{CD} 4{ }^{+} \mathrm{CD} 25^{+}$Treg cells, and it was shown that there was significantly higher expression of these PDE8 isoforms in Teff cells than in Treg cells (Vang et al., 2013). However, expression of rapidly accelerated fibrosarcoma (Raf)-1 in Teff cells was not significantly different from that in Treg cells (Basole et al., 2017).

Previous studies demonstrated that Raf-1 profoundly regulates cell motility (Juliano et al., 2004). A study addressing the role of PDE8 in this process used T cells that were derived from Foxp3gfp.KI mice (Basole et al., 2017). In these mice, expression of FoxP3, a known regulator of the development of functional Treg cell populations, is tagged with green fluorescent protein (GFP). Using Teff and Treg cell populations from these mice immunized with the myelin derived peptide facilitated separate measurements of inhibitor effects on each cell population under identical conditions. A flow chamber model using physiologic shear stress to measure various categories of tethers of $\mathrm{T}$ cell populations to bEnd. 3 cells was employed. PDE8 inhibition using PF-04957325 significantly reduced firm tethers of $\mathrm{CD}^{+}{ }^{+} \mathrm{Foxp}^{+} \mathrm{GFP}^{-}$Teff cells. In contrast, no significant effect of PDE8 inhibition was observed in adhesion assays of $\mathrm{CD}^{+}{ }^{+} \mathrm{Foxp}^{+} \mathrm{GFP}^{+}$Treg cells. It is conceivable that the different sensitivity of Teff and Treg cells to PDE8 inhibition when forming firm adhesive tethers is related to the different expression levels of PDE8A in both cell populations (Basole et al., 2017).

\section{ADHESION OF Teff CELLS TO ENDOTHELIAL CELLS IS REGULATED BY A PDE8A-RAF-1 KINASE SIGNALING COMPLEX}

The studies on PDE8 inhibition were followed by mechanistic investigations testing the role of the signaling complex formed by PDE8A and Raf-1 kinase in regulating adhesion of Teff and Treg cells to endothelial cells (Basole et al., 2017). Both molecules assemble in the cytoplasm whereby PDE8A protects RAF-1 kinase from PKA mediated inhibitory phosphorylation (Brown et al., 2013; Maurice, 2013). Vascular adhesion of T cells has been shown to be regulated by members of the Ras family of signaling molecules (Brown et al., 2014). Disruption of the PDE8A-Raf1 complex by a cell permeable peptide specifically engineered to disrupt this complex (Brown et al., 2013) was tested for its effect on $\mathrm{CD}^{+}{ }^{+} \mathrm{T}$ cell adhesion and migration under shear stress conditions. Adhesion of $\mathrm{CD}^{+}{ }^{+} \mathrm{GFP}^{-}$Foxp $3^{-}$Teff cells to vascular endothelial cells was significantly decreased by the disruptor peptide in experiments employing $\mathrm{CD} 4^{+} \mathrm{T}$ cells isolated from the draining lymph nodes of Foxp $3 g f p$.KI mice immunized with $\mathrm{MOG}_{35-55}$, whereas a scrambled control peptide was without effect. Disruption of the PDE8A-Raf-1 complex by the peptide similarly decreased adhesion, spreading and locomotion of Teff cells to isolated ICAM-1 molecules. In contrast, the use of PF04957325 which targets the enzymatic site of PDE8, did not show comparable effects (Basole et al., 2017). In further comparing the disruptor peptide with the PDE8 enzymatic inhibitor, PF04957325, it was found that adhesion of CD4 ${ }^{+}$Teff or Treg cells via LFA-1 integrin to ICAM-1 was not markedly altered through the exposure to PF-04957325. In contrast the PDE8ARaf-1 disruptor peptide significantly reduced cell adherence, 
spreading and locomotion of $\mathrm{CD}^{+} \mathrm{GFP}^{-}$Foxp3 ${ }^{-}$Teff cells. The disruptor peptide also reduced transient Treg cell adhesion to ICAM-1, while having no effect on firm tether formation and detachment of these cells. Taken together, this indicates the tether formation between LFA-1 and ICAM-1 on T cells and vascular targets is in part regulated by a signaling complex that is formed between PDE8A and Raf-1. The regulation appears to be LFA1 integrin specific in that no significant effects were observed when the VLA-4-VCAM-1 interactions were examined using the comparable assay systems and cells (Basole et al., 2017).

\section{INHIBITION OF PDE8 CATALYTIC ACTIVITY SIGNIFICANTLY SUPPRESSES EXTRACELLULAR SIGNAL-REGULATED KINASE (ERK) PHOSPHORYLATION IN ACTIVATED CD4 ${ }^{+} T$ CELLS}

Inhibition of PDE8 catalytic activity and disruption of the complex of PDE8A-Raf-1 were both investigated for their potential to affect Raf-1 or ERK signaling by analyzing Raf-1 phosphorylation at residue S259 that inhibits its activity (Brown et al., 2013; Maurice, 2013) by PKA and the phosphorylation sites known to activate ERK1/2 in $\mathrm{CD}^{+} \mathrm{T}$ cells that were treated with PF-04957325 or disruptor peptide and polyclonally activated (Basole et al., 2017). Inhibitory Raf-1 phosphorylation at S259 and activating ERK1/2 phosphorylation at residues Thr202/Tyr204 were determined by Western immunoblot. Inhibitor treatment did not affect phosphorylation of Raf-1, but a significant decrease of the phosphorylation of ERK1/2 was seen after inhibitor treatment of Teff cells. These observations demonstrate an effect of PDE8 on the ERK1/2 signaling pathway as has been seen with PDE4 in T cells (Baillie and Houslay, 2005). Of note, the abundance of PDE8A increased in response to PDE8 inhibition. Similar results were reported for PDE7A, PDE3B, PDE4B, and PDE4D which were increased when CAMP was elevated in cells (Jiang et al., 1998; Lee et al., 2002; Moon et al., 2002), and this upregulation apparently occurs with PDE8A as well.

\section{PDE8A-RAF-1 COMPLEX DISRUPTION WITHIN ACTIVATED Teff CELLS LEADS TO RAF-1 AND ERK1/2 PHOSPHORYLATION WITH OPPOSING EFFECTS}

Treatment of $\mathrm{CD}^{+}{ }^{+} \mathrm{T}$ cells with the complex disruptor peptide increases phosphorylation of Raf-1 at the inhibitory site at S259 while phosphorylation of ERK1/2 increases at activating sites at Thr202/Tyr204 (Basole et al., 2017). Based on these observations, it is conceivable that the PDE8A-Raf-1 complex regulates motility of T cells through Raf- 1 and not through the canonical ERK-MAPK pathway. The exact mechanism underlying these experimental results needs to be elucidated since the reported increase in the phosphorylation of ERK within activated Teff cells can be the result of actions of many effectors interacting in this process (Kortum et al., 2013).

\section{PDE8A AND BREAST CANCER CELL MOTILITY}

It has been observed that stimulation of cAMP signaling, in many cases through inhibition of PDEs, inhibits migration and motility of some types of cells, including fibroblasts (Fleming et al., 2004), epithelial cells (Lyle et al., 2008), endothelial cells (Netherton and Maurice, 2005), melanoma cells (Dua and Gude, 2008), colon cancer cells (Murata et al., 2000), pancreatic cancer cells (Burdyga et al., 2013; Zimmerman et al., 2015), bladder cancer cells (Ou et al., 2014), cervical cancer cells (Lee et al., 2014), and breast cancer cells (Dong et al., 2015). In the breast cancer study a complete analysis of the expression of PDE genes at the mRNA and protein level in established estrogen receptor positive and negative breast cancer cell lines and in patients' primary breast cancer biopsies by microarray analysis, qPCR, Western blot analysis, immunofluorescence and immunohistochemistry was performed (Dong et al., 2015). Although a wide range of PDE genes were seen to be expressed in some of these breast cancers by these methods, the PDE8A gene was prominently expressed at the mRNA level in all the breast cancer cells as well as all the breast cancer tissues examined. In addition to its prominent expression in breast cancer cells, expression of PDE8A in the form of an AKAP13-PDE8A fusion transcript has been reported to be highly recurrent in colon cancer cells as well (Nome et al., 2013). Breast cancer cell migration was analyzed both by transwell migration and wound healing assays, and was found to be inhibited by several agonistic cAMP analogs, Fsk, and several PDE inhibitors, in particular DP and the PDE8 selective inhibitor, PF-04957325. Therefore, consistent with our observation of PDE8A being important in the regulation of lymphocyte chemotaxis, it may also be an important regulator, and thus an important target for control of breast cancer cell migration as well.

\section{CONCLUSION}

Numerous studies demonstrate that $\mathrm{T}$ cell adhesion and migration under shear stress conditions are regulated by the enzymatic activity of PDE8 proteins. Additionally, the PDE8ARaf-1 kinase signaling complex has been identified as a functional site for PDE8A controlling T cell motility (Figure 1). Inasmuch as treatment with the peptide designed to disrupt the PDE8A-Raf1 complex led to phosphorylation of Raf-1 at an inhibitory site but phosphorylation of ERK1/2 at activating sites, it suggests that PDE8 displacement from the complex exerts a Raf-1 dependent but ERK independent effect on $\mathrm{T}$ cell motility. Thus, it is conceivable that the effect of PDE8 inhibition on the formation of tethers and directed migration by T cells is mediated by Raf-1 but not ERK. This model is supported by reports demonstrating regulation of cell motility by Raf-1 and B-Raf through Rho GTPases regulating the actin cytoskeleton and focal adhesions 
(Ehrenreiter et al., 2005; Klein et al., 2008). The studies on PDE8 identify a novel signaling complex of PDE8-RAF regulating $\mathrm{CD}^{+}{ }^{+} \mathrm{T}$ cell motility. Upon $\mathrm{T}$ cell activation through the TCR, Raf-1 links Ras activation to MAPK signaling (Kortum et al., 2013). Of note, B-Raf most strongly interacts with Ras (Marais et al., 1997; Weber et al., 2000) and activates ERK (Pritchard et al., 1995, 2004; Wojnowski et al., 2000) while cell proliferation and ERK activation are independent of Raf1. In contrast, Raf- 1 is capable of activating Rho and inducing subsequent downstream events in migrating cells without MAPK activity (Ehrenreiter et al., 2005). Thus, MAPKs have been known to act independently in specific signaling pathways. Activation of ERK independent of Ras/Raf-1 can also occur through activation of T cells through the TCR (Kortum et al., 2013). An effect on $T$ cell function that is independent of ERK is also suggested by the finding that PDE8 inhibition does not affect $\mathrm{T}$ cell proliferation (Vang et al., 2010, 2016). PDE4 inhibition has been shown to suppress $\mathrm{T}$ cell proliferation and ERK1 signaling (Norambuena et al., 2009), but T cell motility is little affected (Lerner and Epstein, 2006; Vang et al., 2016). Collectively, reports over the last few years suggest that PDE8

\section{REFERENCES}

Abrahamsen, H., Baillie, G., Ngai, J., Vang, T., Nika, K., Ruppelt, A., et al. (2004). TCR- and CD28-mediated recruitment of phosphodiesterase 4 to lipid rafts potentiates TCR signaling. J. Immunol. 173, 4847-4858. doi: 10.4049/ jimmunol.173.8.4847

Ahmad, F., Murata, T., Shimizu, K., Degerman, E., Maurice, D., and Manganiello, V. (2015). Cyclic nucleotide phosphodiesterases: important signaling modulators and therapeutic targets. Oral Dis. 21, e25-e50.

Akama, T., Baker, S. J., Zhang, Y. K., Hernandez, V., Zhou, H., Sanders, V., et al. (2009). Discovery and structure-activity study of a novel benzoxaborole antiinflammatory agent (AN2728) for the potential topical treatment of psoriasis and atopic dermatitis. Bioorg. Med. Chem. Lett. 19, 2129-2132. doi: 10.1016/j. bmcl.2009.03.007

Amarandi, R. M., Hjorto, G. M., Rosenkilde, M. M., and Karlshoj, S. (2016). Probing biased signaling in chemokine receptors. Methods Enzymol. 570, 155 186. doi: 10.1016/bs.mie.2015.09.001

Arp, J., Kirchhof, M. G., Baroja, M. L., Nazarian, S. H., Chau, T. A., Strathdee, C. A., et al. (2003). Regulation of T-cell activation by phosphodiesterase 4B2 requires its dynamic redistribution during immunological synapse formation. Mol. Cell. Biol. 23, 8042-8057. doi: 10.1128/mcb.23.22.8042-8057.2003

Ashikaga, T., Strada, S. J., and Thompson, W. J. (1997). Altered expression of cyclic nucleotide phosphodiesterase isozymes during culture of aortic endothelial cells. Biochem. Pharmacol. 54, 1071-1079. doi: 10.1016/s0006-2952(97)002876

Asirvatham, A. L., Galligan, S. G., Schillace, R. V., Davey, M. P., Vasta, V., Beavo, J. A., et al. (2004). A-kinase anchoring proteins interact with phosphodiesterases in T lymphocyte cell lines. J. Immunol. 173, 4806-4814. doi: 10.4049/jimmunol. 173.8.4806

Baillie, G. S. (2009). Compartmentalized signalling: spatial regulation of cAMP by the action of compartmentalized phosphodiesterases. FEBS J. 276, 1790-1799. doi: $10.1111 /$ j.1742-4658.2009.06926.x

Baillie, G. S., and Houslay, M. D. (2005). Arrestin times for compartmentalised cAMP signalling and phosphodiesterase-4 enzymes. Curr. Opin. Cell Biol. 17, 129-134. doi: 10.1016/j.ceb.2005.01.003

Baillie, G. S., Tejeda, G. S., and Kelly, M. P. (2019). Therapeutic targeting of 3',5'cyclic nucleotide phosphodiesterases: inhibition and beyond. Nat. Rev. Drug Discov. 18, 770-796. doi: 10.1038/s41573-019-0033-4

Barnette, M. S., Christensen, S. B., Essayan, D. M., Grous, M., Prabhakar, U., Rush, J. A., et al. (1998). SB 207499 (Ariflo), a potent and selective second-generation and the PDE8A-Raf-1 signaling complex selectively regulate the motility of $\mathrm{T}$ cells but not $\mathrm{T}$ cell proliferation and support the notion that PDE8A exerts its action primarily on Raf-1 kinase and not on MAPK signaling.

\section{AUTHOR CONTRIBUTIONS}

All authors researched the literature, wrote the manuscript, and reviewed and approved the final version. SB prepared the figure. $\mathrm{CB}$ and $\mathrm{PE}$ reviewed and approved the final figure.

\section{FUNDING}

We received support from the NMSS (grant no. RG 4544A1/1) on the Role of PDE8 in EAE, from the Smart Family Foundation on Targeting PDE8 for Treatment of Autoimmune Diseases and the Lea's Foundation for Leukemia Research Inc. on phosphodiesterase as a Target for Leukemia Treatment. The funders had no influence on the research design and experiments.

phosphodiesterase 4 inhibitor: in vitro anti-inflammatory actions. J. Pharmacol. Exp. Ther. 284, 420-426.

Basole, C. P., Nguyen, R. K., Lamothe, K., Vang, A., Clark, R., Baillie, G. S., et al. (2017). PDE8 controls CD4(+) T cell motility through the PDE8A-Raf-1 kinase signaling complex. Cell Signal. 40, 62-72. doi: 10.1016/j.cellsig.2017.08.007

Beavo, J., Houslay, M., and Francis, S. (2007). "Cyclic nucleotide phosphodiesterase superfamily," in Cyclic Nucleotide Phosphodiesterases in Health and Disease, eds J. A. Beavo, S. H. Francis, and M. D. Houslay (New York, NY: CRC Press), 3-18. doi: 10.1201/9781420020847-1

Bender, A. T., and Beavo, J. A. (2006). Cyclic nucleotide phosphodiesterases: molecular regulation to clinical use. Pharmacol. Rev. 58, 488-520. doi: 10.1124/ pr.58.3.5

Ben-Sasson, S. Z., Hu-Li, J., Quiel, J., Cauchetaux, S., Ratner, M., Shapira, I., et al. (2009). IL-1 acts directly on CD4 T cells to enhance their antigen-driven expansion and differentiation. Proc. Natl. Acad. Sci. U.S.A. 106, 7119-7124. doi: 10.1073/pnas.0902745106

Ben-Sasson, S. Z., Wang, K., Cohen, J., and Paul, W. E. (2013). IL-1beta strikingly enhances antigen-driven CD4 and CD8 T-cell responses. Cold Spring Harb. Symp. Quant. Biol. 78, 117-124. doi: 10.1101/sqb.2013.78.021246

Bielekova, B., Lincoln, A., Mcfarland, H., and Martin, R. (2000). Therapeutic potential of phosphodiesterase-4 and -3 inhibitors in Th1-mediated autoimmune diseases. J. Immunol. 164, 1117-1124. doi: 10.4049/jimmunol.164.2.1117

Bischoff, E. (2004). Potency, selectivity, and consequences of nonselectivity of PDE inhibition. Int. J. Impot. Res. 16(Suppl. 1), S11-S14.

Biton, A., Ansorge, S., Bank, U., Tager, M., Reinhold, D., and Brocke, S. (2011). Divergent actions by inhibitors of DP IV and APN family enzymes on CD4+ Teff cell motility and functions. Immunobiology 216, 1295-1301. doi: 10.1016/ j.imbio.2011.07.001

Bjorgo, E., Moltu, K., and Tasken, K. (2011). Phosphodiesterases as targets for modulating T-cell responses. Handb. Exp. Pharmacol. 204, 345-363. doi: 10. 1007/978-3-642-17969-3_15

Bjorgo, E., Solheim, S. A., Abrahamsen, H., Baillie, G. S., Brown, K. M., Berge, T., et al. (2010). Cross talk between phosphatidylinositol 3-kinase and cyclic AMP (cAMP)-protein kinase a signaling pathways at the level of a protein kinase B/beta-arrestin/cAMP phosphodiesterase 4 complex. Mol. Cell. Biol. 30, 1660-1672. doi: 10.1128/mcb.00696-09

Bjorgo, E., and Tasken, K. (2006). Role of cAMP phosphodiesterase 4 in regulation of T-cell function. Crit. Rev. Immunol. 26, 443-451. doi: 10.1615/ critrevimmunol.v26.i5.40 
Blair, C. M., and Baillie, G. S. (2019). Reshaping cAMP nanodomains through targeted disruption of compartmentalised phosphodiesterase signalosomes. Biochem. Soc. Trans. 47, 1405-1414. doi: 10.1042/bst20190252

Blair, C. M., Walsh, N. M., Littman, B. H., Marcoux, F. W., and Baillie, G. S. (2019). Targeting B-Raf inhibitor resistant melanoma with novel cell penetrating peptide disrupters of PDE8A - C-Raf. BMC Cancer 19:266.

Blanco, F. C., Soria, M. A., Klepp, L. I., and Bigi, F. (2017). ERAP1 and PDE8A are downregulated in cattle protected against bovine tuberculosis. J. Mol. Microbiol. Biotechnol. 27, 237-245. doi: 10.1159/000479183

Blokland, A., Heckman, P., Vanmierlo, T., Schreiber, R., Paes, D., and Prickaerts, J. (2019). Phosphodiesterase type 4 inhibition in CNS diseases. Trends Pharmacol. Sci. 40, 971-985. doi: 10.1016/j.tips.2019.10.006

Bloom, T. J., and Beavo, J. A. (1996). Identification and tissue-specific expression of PDE7 phosphodiesterase splice variants. Proc. Natl. Acad. Sci. U.S.A. 93, 14188-14192. doi: 10.1073/pnas.93.24.14188

Booiman, T., Cobos Jimenez, V., Van Dort, K. A., Van 'T Wout, A. B., and Kootstra, N. A. (2014). Phosphodiesterase 8a supports HIV-1 replication in macrophages at the level of reverse transcription. PLoS One 9:e109673. doi: 10.1371/journal. pone.0109673

Bopp, T., Becker, C., Klein, M., Klein-Hessling, S., Palmetshofer, A., Serfling, E., et al. (2007). Cyclic adenosine monophosphate is a key component of regulatory T cell-mediated suppression. J. Exp. Med. 204, 1303-1310. doi: 10.1084/jem. 20062129

Bopp, T., Dehzad, N., Reuter, S., Klein, M., Ullrich, N., Stassen, M., et al. (2009). Inhibition of cAMP degradation improves regulatory T cell-mediated suppression. J. Immunol. 182, 4017-4024. doi: 10.4049/jimmunol.080 3310

Bourne, H. R., Lichtenstein, L. M., Melmon, K. L., Henney, C. S., Weinstein, Y., and Shearer, G. M. (1974). Modulation of inflammation and immunity by cyclic AMP. Science 184, 19-28. doi: 10.1126/science.184.4132.19

Brocke, S., Piercy, C., Steinman, L., Weissman, I. L., and Veromaa, T. (1999). Antibodies to CD44 and integrin alpha4, but not L-selectin, prevent central nervous system inflammation and experimental encephalomyelitis by blocking secondary leukocyte recruitment. Proc. Natl. Acad. Sci. U.S.A. 96, 6896-6901. doi: 10.1073/pnas.96.12.6896

Brocke, S., Quigley, L., Mcfarland, H. F., and Steinman, L. (1996). Isolation and characterization of autoreactive $\mathrm{T}$ cells in experimental autoimmune encephalomyelitis of the mouse. Methods 9, 458-462. doi: 10.1006/meth.1996. 0053

Brown, K. M., Day, J. P., Huston, E., Zimmermann, B., Hampel, K., Christian, F., et al. (2013). Phosphodiesterase-8A binds to and regulates Raf-1 kinase. Proc. Natl. Acad. Sci. U.S.A. 110, E1533-E1542.

Brown, W. S., Khalili, J. S., Rodriguez-Cruz, T. G., Lizee, G., and Mcintyre, B. W. (2014). B-Raf regulation of integrin alpha4betal-mediated resistance to shear stress through changes in cell spreading and cytoskeletal association in T cells. J. Biol. Chem. 289, 23141-23153. doi: 10.1074/jbc.m114.562918

Burdyga, A., Conant, A., Haynes, L., Zhang, J., Jalink, K., Sutton, R., et al. (2013). cAMP inhibits migration, ruffling and paxillin accumulation in focal adhesions of pancreatic ductal adenocarcinoma cells: effects of PKA and EPAC. Biochim. Biophys. Acta 1833, 2664-2672. doi: 10.1016/j.bbamcr.2013.06.011

Callender, V. D., Alexis, A. F., Stein Gold, L. F., Lebwohl, M. G., Paller, A. S., Desai, S. R., et al. (2019). Efficacy and safety of crisaborole ointment, 2\%, for the treatment of mild-to-moderate atopic dermatitis across racial and ethnic groups. Am. J. Clin. Dermatol. 20, 711-723. doi: 10.1007/s40257-01900450-w

Chen, C., Wickenheisser, J., Ewens, K. G., Ankener, W., Legro, R. S., Dunaif, A., et al. (2009). PDE8A genetic variation, polycystic ovary syndrome and androgen levels in women. Mol. Hum. Reprod. 15, 459-469. doi: 10.1093/molehr/gap035

Chilcoat, C. D., Sharief, Y., and Jones, S. L. (2008). Tonic protein kinase A activity maintains inactive beta 2 integrins in unstimulated neutrophils by reducing myosin light-chain phosphorylation: role of myosin light-chain kinase and Rho kinase. J. Leukoc Biol. 83, 964-971. doi: 10.1189/jlb.0405192

Chimienti, F., Cavarec, L., Vincent, L., Salvetat, N., Arango, V., Underwood, M. D., et al. (2019). Brain region-specific alterations of RNA editing in PDE8A mRNA in suicide decedents. Transl. Psychiatry 9:91.

Cinamon, G., Grabovsky, V., Winter, E., Franitza, S., Feigelson, S., Shamri, R., et al. (2001). Novel chemokine functions in lymphocyte migration through vascular endothelium under shear flow. J. Leukoc Biol. 69, 860-866.
Claveau, D., Chen, S. L., O’keefe, S., Zaller, D. M., Styhler, A., Liu, S., et al. (2004). Preferential inhibition of $\mathrm{T}$ helper 1 , but not $\mathrm{T}$ helper 2 , cytokines in vitro by L-826,141 [4-[2-(3,4-Bisdifluromethoxyphenyl)-2-[4-(1,1,1,3,3,3-hexafluoro-2hydroxy propan-2-yl)-phenyl]-ethyl]3-methylpyridine-1-oxide], a potent and selective phosphodiesterase 4 inhibitor. J. Pharmacol. Exp. Ther. 310, 752-760. doi: 10.1124/jpet.103.064691

Conti, M., Nemoz, G., Sette, C., and Vicini, E. (1995). Recent progress in understanding the hormonal regulation of phosphodiesterases. Endocr. Rev. 16, 370-389. doi: 10.1210/edrv-16-3-370

Conti, M., and Swinnen, J. V. (1990). "Structure and function of the rolipramsensitive low-Km cyclic AMP phosphodiesterases: a family of highly related enzymes," in Cyclic Nucleotide Phosphodiesterases: Structure, Regulation and Drug Action, eds J. Beavo and M. D. Houslay (West Sussex: John Wiley \& Sons Ltd.), 243-265.

De Souza, A., Strober, B. E., Merola, J. F., Oliver, S., and Franks, A. G. Jr. (2012). Apremilast for discoid lupus erythematosus: results of a phase 2, open-label, single-arm, pilot study. J. Drugs Dermatol. 11, 1224-1226.

Demirbas, D., Wyman, A. R., Shimizu-Albergine, M., Cakici, O., Beavo, J. A., and Hoffman, C. S. (2013). A yeast-based chemical screen identifies a PDE inhibitor that elevates steroidogenesis in mouse Leydig cells via PDE8 and PDE4 inhibition. PLoS One 8:e71279. doi: 10.1371/journal.pone.0071279

DeNinno, M. P. (2012). Future directions in phosphodiesterase drug discovery. Bioorg. Med. Chem. Lett. 22, 6794-6800. doi: 10.1016/j.bmcl.2012.09.028

DeNinno, M. P., Wright, S. W., Visser, M. S., Etienne, J. B., Moore, D. E., Olson, T. V., et al. (2011). 1,5-Substituted nipecotic amides: selective PDE8 inhibitors displaying diastereomer-dependent microsomal stability. Bioorg. Med. Chem. Lett. 21, 3095-3098. doi: 10.1016/j.bmcl.2011.03.022

Dong, C., Virtucio, C., Zemska, O., Baltazar, G., Zhou, Y., Baia, D., et al. (2016). Treatment of skin inflammation with benzoxaborole phosphodiesterase inhibitors: selectivity, cellular activity, and effect on cytokines associated with skin inflammation and skin architecture changes. J. Pharmacol. Exp. Ther. 358, 413-422. doi: 10.1124/jpet.116.232819

Dong, H., Claffey, K. P., Brocke, S., and Epstein, P. M. (2015). Inhibition of breast cancer cell migration by activation of cAMP signaling. Breast Cancer Res. Treat. 152, 17-28. doi: 10.1007/s10549-015-3445-9

Dong, H., Osmanova, V., Epstein, P. M., and Brocke, S. (2006). Phosphodiesterase 8 (PDE8) regulates chemotaxis of activated lymphocytes. Biochem. Biophys. Res. Commun. 345, 713-719. doi: 10.1016/j.bbrc.2006.04.143

Dong, H., Zitt, C., Auriga, C., Hatzelmann, A., and Epstein, P. M. (2010). Inhibition of PDE3, PDE4 and PDE7 potentiates glucocorticoid-induced apoptosis and overcomes glucocorticoid resistance in CEM T leukemic cells. Biochem. Pharmacol. 79, 321-329. doi: 10.1016/j.bcp.2009.09.001

Dua, P., and Gude, R. P. (2008). Pentoxifylline impedes migration in B16F10 melanoma by modulating Rho GTPase activity and actin organisation. Eur. J. Cancer 44, 1587-1595. doi: 10.1016/j.ejca.2008.04.009

Ehrenreiter, K., Piazzolla, D., Velamoor, V., Sobczak, I., Small, J. V., Takeda, J., et al. (2005). Raf-1 regulates Rho signaling and cell migration. J. Cell. Biol. 168, 955-964. doi: 10.1083/jcb.200409162

Ekholm, D., Hemmer, B., Gao, G., Vergelli, M., Martin, R., and Manganiello, V. (1997). Differential expression of cyclic nucleotide phosphodiesterase 3 and 4 activities in human $\mathrm{T}$ cell clones specific for myelin basic protein. J. Immunol. $159,1520-1529$.

Epstein, P. M., and Hachisu, R. (1984). Cyclic nucleotide phosphodiesterase in normal and leukemic human lymphocytes and lymphoblasts. Adv. Cyclic Nucleotide Protein Phosphorylation Res. 16, 303-324.

Epstein, P. M., Mills, J. S., Hersh, E. M., Strada, S. J., and Thompson, W. J. (1980). Activation of cyclic nucleotide phosphodiesterase from isolated human peripheral blood lymphocytes by mitogenic agents. Cancer Res. 40, 379-386.

Epstein, P. M., Moraski, S. Jr., and Hachisu, R. (1987). Identification and characterization of a Ca2+-calmodulin-sensitive cyclic nucleotide phosphodiesterase in a human lymphoblastoid cell line. Biochem. J. 243, 533-539. doi: 10.1042/bj2430533

Epstein, P. M., Strada, S. J., Sarada, K., and Thompson, W. J. (1982). Catalytic and kinetic properties of purified high-affinity cyclic AMP phosphodiesterase from dog kidney. Arch. Biochem. Biophys. 218, 119-133. doi: 10.1016/0003-9861(82) 90327-7

Erdogan, S., and Houslay, M. D. (1997). Challenge of human Jurkat T-cells with the adenylate cyclase activator forskolin elicits major changes in cAMP 
phosphodiesterase (PDE) expression by up-regulating PDE3 and inducing PDE4D1 and PDE4D2 splice variants as well as down-regulating a novel PDE4A splice variant. Biochem. J. 321(Pt 1), 165-175. doi: 10.1042/bj321 0165

Essayan, D. M., Huang, S. K., Kagey-Sobotka, A., and Lichtenstein, L. M. (1997). Differential efficacy of lymphocyte- and monocyte-selective pretreatment with a type 4 phosphodiesterase inhibitor on antigen-driven proliferation and cytokine gene expression. J. Allergy Clin. Immunol. 99, 28-37. doi: 10.1016/ s0091-6749(97)81041-x

Fawcett, L., Baxendale, R., Stacey, P., Mcgrouther, C., Harrow, I., Soderling, S., et al. (2000). Molecular cloning and characterization of a distinct human phosphodiesterase gene family: PDE11A. Proc. Natl. Acad. Sci. U.S.A. 97, 3702-3707. doi: 10.1073/pnas.97.7.3702

Fisher, D. A., Smith, J. F., Pillar, J. S., St Denis, S. H., and Cheng, J. B. (1998a). Isolation and characterization of PDE8A, a novel human cAMPspecific phosphodiesterase. Biochem. Biophys. Res. Commun. 246, 570-577. doi: 10.1006/bbrc. 1998.8684

Fisher, D. A., Smith, J. F., Pillar, J. S., St Denis, S. H., and Cheng, J. B. (1998b). Isolation and characterization of PDE9A, a novel human cGMP-specific phosphodiesterase. J. Biol. Chem. 273, 15559-15564. doi: 10.1074/jbc.273.25. 15559

Fleming, Y. M., Frame, M. C., and Houslay, M. D. (2004). PDE4-regulated cAMP degradation controls the assembly of integrin-dependent actin adhesion structures and REF52 cell migration. J. Cell Sci. 117, 2377-2388. doi: 10.1242/ jcs.01096

Francis, S. H., Houslay, M. D., and Conti, M. (2011). Phosphodiesterase inhibitors: factors that influence potency, selectivity, and action. Handb. Exp. Pharmacol. 204, 47-84. doi: 10.1007/978-3-642-17969-3_2

Francis, S. H., Thomas, M. K., and Corbin, J. D. (1990). "Cyclic GMPbinding cyclic GMP-specific phosphodiesterase from lung," in Cyclic Nucleotide Phosphodiesterases: Structure, Regulation and Drug Action, eds J. Beavo and M. D. Houslay (West Sussex: John Wiley \& Sons Ltd.), 117-139.

Fujishige, K., Kotera, J., Michibata, H., Yuasa, K., Takebayashi, S., Okumura, K., et al. (1999a). Cloning and characterization of a novel human phosphodiesterase that hydrolyzes both cAMP and cGMP (PDE10A). J. Biol. Chem. 274, 18438-18445. doi: 10.1074/jbc.274.26.18438

Fujishige, K., Kotera, J., and Omori, K. (1999b). Striatum- and testis-specific phosphodiesterase PDE10A isolation and characterization of a rat PDE10A. Eur. J. Biochem. 266, 1118-1127. doi: 10.1046/j.1432-1327.1999.00963.x

Gamanuma, M., Yuasa, K., Sasaki, T., Sakurai, N., Kotera, J., and Omori, K. (2003). Comparison of enzymatic characterization and gene organization of cyclic nucleotide phosphodiesterase 8 family in humans. Cell Signal. 15, 565-574. doi: 10.1016/s0898-6568(02)00146-8

Gantner, F., Gotz, C., Gekeler, V., Schudt, C., Wendel, A., and Hatzelmann, A. (1998). Phosphodiesterase profile of human B lymphocytes from normal and atopic donors and the effects of PDE inhibition on B cell proliferation. $\mathrm{Br}$. J. Pharmacol. 123, 1031-1038. doi: 10.1038/sj.bjp.0701688

Gantner, F., Kusters, S., Wendel, A., Hatzelmann, A., Schudt, C., and Tiegs, G. (1997a). Protection from T cell-mediated murine liver failure by phosphodiesterase inhibitors. J. Pharmacol. Exp. Ther. 280, 53-60.

Gantner, F., Tenor, H., Gekeler, V., Schudt, C., Wendel, A., and Hatzelmann, A. (1997b). Phosphodiesterase profiles of highly purified human peripheral blood leukocyte populations from normal and atopic individuals: a comparative study. J. Allergy Clin. Immunol. 100, 527-535. doi: 10.1016/s0091-6749(97) 70146-5

Gardner, C., Robas, N., Cawkill, D., and Fidock, M. (2000). Cloning and characterization of the human and mouse PDE7B, a novel cAMP-specific cyclic nucleotide phosphodiesterase. Biochem. Biophys. Res. Commun. 272, 186-192. doi: $10.1006 /$ bbrc. 2000.2743

Gavin, M. A., Rasmussen, J. P., Fontenot, J. D., Vasta, V., Manganiello, V. C., Beavo, J. A., et al. (2007). Foxp3-dependent programme of regulatory T-cell differentiation. Nature 445, 771-775. doi: 10.1038/nature05543

Giembycz, M. A. (2000). Phosphodiesterase 4 inhibitors and the treatment of asthma: where are we now and where do we go from here? Drugs 59, 193-212. doi: 10.2165/00003495-200059020-00004

Giembycz, M. A., Corrigan, C. J., Seybold, J., Newton, R., and Barnes, P. J. (1996). Identification of cyclic AMP phosphodiesterases 3, 4 and 7 in human CD4+ and CD8+ T-lymphocytes: role in regulating proliferation and the biosynthesis of interleukin-2. Br. J. Pharmacol. 118, 1945-1958. doi: 10.1111/j.1476-5381. 1996.tb15629.x

Gillespie, P. G. (1990). "Phosphodiesterases in visual transduction by rods and cones," in Cyclic Nucleotide Phosphodiesterases: Structure, Regulation and Drug Action, eds J. Beavo and M. D. Houslay (West Sussex: John Wiley \& Sons Ltd.), 163-183.

Gillespie, P. G., and Beavo, J. A. (1989). Inhibition and stimulation of photoreceptor phosphodiesterases by dipyridamole and M\&B 22,948. Mol. Pharmacol. 36, 773-781.

Glavas, N. A., Ostenson, C., Schaefer, J. B., Vasta, V., and Beavo, J. A. (2001). T cell activation up-regulates cyclic nucleotide phosphodiesterases 8A1 and 7A3. Proc. Natl. Acad. Sci. U.S.A. 98, 6319-6324. doi: 10.1073/pnas.101131098

Goldfinger, L. E., Han, J., Kiosses, W. B., Howe, A. K., and Ginsberg, M. H. (2003). Spatial restriction of alpha4 integrin phosphorylation regulates lamellipodial stability and alpha4beta1-dependent cell migration. J. Cell Biol. 162, 731-741. doi: $10.1083 /$ jcb. 200304031

Gonzalez-Garcia, C., Bravo, B., Ballester, A., Gomez-Perez, R., Eguiluz, C., Redondo, M., et al. (2013). Comparative assessment of PDE 4 and 7 inhibitors as therapeutic agents in experimental autoimmune encephalomyelitis. $\mathrm{Br}$. J. Pharmacol. 170, 602-613. doi: 10.1111/bph.12308

Goraya, T. A., and Cooper, D. M. (2005). Ca2+-calmodulin-dependent phosphodiesterase (PDE1): current perspectives. Cell Signal. 17, 789-797. doi: 10.1016/j.cellsig.2004.12.017

Goto, M., Murakawa, M., Kadoshima-Yamaoka, K., Tanaka, Y., Inoue, H., Murafuji, H., et al. (2009). Phosphodiesterase 7A inhibitor ASB16165 suppresses proliferation and cytokine production of NKT cells. Cell Immunol. 258, 147-151. doi: 10.1016/j.cellimm.2009.04.005

Guo, J., Watson, A., Kempson, J., Carlsen, M., Barbosa, J., Stebbins, K., et al. (2009). Identification of potent pyrimidine inhibitors of phosphodiesterase 7 (PDE7) and their ability to inhibit T cell proliferation. Bioorg. Med. Chem. Lett. 19, 1935-1938. doi: 10.1016/j.bmcl.2009.02.060

Han, P., Zhu, X., and Michaeli, T. (1997). Alternative splicing of the high affinity cAMP-specific phosphodiesterase (PDE7A) mRNA in human skeletal muscle and heart. J. Biol. Chem. 272, 16152-16157. doi: 10.1074/jbc.272.26. 16152

Hatzelmann, A., Morcillo, E. J., Lungarella, G., Adnot, S., Sanjar, S., Beume, R., et al. (2010). The preclinical pharmacology of roflumilast-a selective, oral phosphodiesterase 4 inhibitor in development for chronic obstructive pulmonary disease. Pulm. Pharmacol. Ther. 23, 235-256. doi: 10.1016/j.pupt. 2010.03.011

Hatzelmann, A., and Schudt, C. (2001). Anti-inflammatory and immunomodulatory potential of the novel PDE4 inhibitor roflumilast in vitro. J. Pharmacol. Exp. Ther. 297, 267-279.

Hayashi, M., Matsushima, K., Ohashi, H., Tsunoda, H., Murase, S., Kawarada, Y., et al. (1998). Molecular cloning and characterization of human PDE8B, a novel thyroid-specific isozyme of $3^{\prime}, 5^{\prime}$-cyclic nucleotide phosphodiesterase. Biochem. Biophys. Res. Commun. 250, 751-756. doi: 10.1006/bbrc.1998.9379

Hayashi, M., Shimada, Y., Nishimura, Y., Hama, T., and Tanaka, T. (2002). Genomic organization, chromosomal localization, and alternative splicing of the human phosphodiesterase 8B gene. Biochem. Biophys. Res. Commun. 297, 1253-1258. doi: 10.1016/s0006-291x(02)02371-9

Healy, L. M., and Antel, J. P. (2016). Sphingosine-1-phosphate receptors in the central nervous and immune systems. Curr. Drug Targets 17, 1841-1850. doi: $10.2174 / 1389450116666151001112710$

Hetman, J. M., Robas, N., Baxendale, R., Fidock, M., Phillips, S. C., Soderling, S. H., et al. (2000a). Cloning and characterization of two splice variants of human phosphodiesterase 11A. Proc. Natl. Acad. Sci. U.S.A. 97, 12891-12895. doi: $10.1073 /$ pnas. 200355397

Hetman, J. M., Soderling, S. H., Glavas, N. A., and Beavo, J. A. (2000b). Cloning and characterization of PDE7B, a cAMP-specific phosphodiesterase. Proc. Natl. Acad. Sci. U.S.A. 97, 472-476. doi: 10.1073/pnas.97.1.472

Houslay, M. D., Sullivan, M., and Bolger, G. B. (1998). The multienzyme PDE4 cyclic adenosine monophosphate-specific phosphodiesterase family: intracellular targeting, regulation, and selective inhibition by compounds exerting anti-inflammatory and antidepressant actions. Adv. Pharmacol. 44, 225-342. doi: 10.1016/s1054-3589(08)60128-3

Huang, Y., Wu, X. N., Zhou, Q., Wu, Y., Zheng, D., Li, Z., et al. (2020). Rational design of 2-chloroadenine derivatives as highly selective phosphodiesterase 
8A inhibitors. J. Med. Chem. 63, 15852-15863. doi: 10.1021/acs.jmedchem. 0c01573

Jankowska, A., Swierczek, A., Chlon-Rzepa, G., Pawlowski, M., and Wyska, E. (2017). PDE7-selective and dual inhibitors: advances in chemical and biological research. Curr. Med. Chem. 24, 673-700. doi: 10.2174/ 0929867324666170116125159

Jarnagin, K., Chanda, S., Coronado, D., Ciaravino, V., Zane, L. T., Guttman-Yassky, E., et al. (2016). Crisaborole topical ointment, 2\%: a nonsteroidal, topical, antiinflammatory phosphodiesterase 4 inhibitor in clinical development for the treatment of atopic dermatitis. J. Drugs Dermatol. 15, 390-396.

Jiang, X., Paskind, M., Weltzien, R., and Epstein, P. M. (1998). Expression and regulation of mRNA for distinct isoforms of cAMP-specific PDE-4 in mitogen-stimulated and leukemic human lymphocytes. Cell Biochem. Biophys. 28, 135-160. doi: 10.1007/bf02737809

Jimenez, J. L., Iniguez, M. A., Munoz-Fernandez, M. A., and Fresno, M. (2004). Effect of phosphodiesterase 4 inhibitors on NFAT-dependent cyclooxygenase-2 expression in human T lymphocytes. Cell Signal. 16, 1363-1373. doi: 10.1016/ j.cellsig.2004.04.002

Jin, S. L., Bushnik, T., Lan, L., and Conti, M. (1998). Subcellular localization of rolipram-sensitive, cAMP-specific phosphodiesterases. Differential targeting and activation of the splicing variants derived from the PDE4D gene. J. Biol. Chem. 273, 19672-19678. doi: 10.1074/jbc.273.31.19672

Jin, S. L., Goya, S., Nakae, S., Wang, D., Bruss, M., Hou, C., et al. (2010). Phosphodiesterase $4 \mathrm{~B}$ is essential for $\mathrm{T}(\mathrm{H}) 2$-cell function and development of airway hyperresponsiveness in allergic asthma. J. Allergy Clin. Immunol. 126, 1252-1259.e1212.

Johnstone, T. B., Smith, K. H., Koziol-White, C. J., Li, F., Kazarian, A. G., Corpuz, M. L., et al. (2017). PDE8 is expressed in human airway smooth muscle and selectively regulates cAMP signaling by beta2AR-AC6. Am. J. Respir Cell Mol. Biol. 58, 530-541. doi: 10.1165/rcmb.2017-0294oc

Juliano, R. L., Reddig, P., Alahari, S., Edin, M., Howe, A., and Aplin, A. (2004). Integrin regulation of cell signalling and motility. Biochem. Soc. Trans. 32, 443-446. doi: 10.1042/bst0320443

Kadoshima-Yamaoka, K., Murakawa, M., Goto, M., Tanaka, Y., Inoue, H., Murafuji, H., et al. (2009). Effect of phosphodiesterase 7 inhibitor ASB16165 on development and function of cytotoxic T lymphocyte. Int. Immunopharmacol. 9, 97-102. doi: 10.1016/j.intimp.2008.10.005

Kakkar, R., Raju, R. V., and Sharma, R. K. (1999). Calmodulin-dependent cyclic nucleotide phosphodiesterase (PDE1). Cell Mol. Life Sci. 55, 1164-1186. doi: 10.1007/s000180050364

Kambayashi, J., Liu, Y., Sun, B., Shakur, Y., Yoshitake, M., and Czerwiec, F. (2003). Cilostazol as a unique antithrombotic agent. Curr. Pharm. Des. 9, 2289-2302. doi: $10.2174 / 1381612033453910$

Kanda, N., and Watanabe, S. (2001). Regulatory roles of adenylate cyclase and cyclic nucleotide phosphodiesterases 1 and 4 in interleukin-13 production by activated human T cells. Biochem. Pharmacol. 62, 495-507. doi: 10.1016/s00062952(01)00688-8

Kelly, M. P. (2018). Cyclic nucleotide signaling changes associated with normal aging and age-related diseases of the brain. Cell Signal. 42, 281-291. doi: 10.1016/j.cellsig.2017.11.004

Klein, R. M., Spofford, L. S., Abel, E. V., Ortiz, A., and Aplin, A. E. (2008). BRAF regulation of Rnd3 participates in actin cytoskeletal and focal adhesion organization. Mol. Biol. Cell 19, 498-508. doi: 10.1091/mbc.e07-09-0895

Kobayashi, T., Gamanuma, M., Sasaki, T., Yamashita, Y., Yuasa, K., Kotera, J., et al. (2003). Molecular comparison of rat cyclic nucleotide phosphodiesterase 8 family: unique expression of PDE8B in rat brain. Gene 319, 21-31. doi: 10.1016/s0378-1119(03)00809-6

Komas, N., Movsesian, M., Kedov, S., Degerman, E., Belfrage, P., and Manganiello, V. (1996). "cGMP-inhibited phosphodiesterases (PDE3)," in Phosphodiesterase Inhibitors, eds C. Schudt, G. Dent, and K. F. Rabe (London: Academic Press), 89-110. doi: 10.1016/b978-012210720-7/50008-3

Kortum, R. L., Rouquette-Jazdanian, A. K., and Samelson, L. E. (2013). Ras and extracellular signal-regulated kinase signaling in thymocytes and T cells. Trends Immunol. 34, 259-268. doi: 10.1016/j.it.2013.02.004

Kotera, J., Fujishige, K., Akatsuka, H., Imai, Y., Yanaka, N., and Omori, K. (1998). Novel alternative splice variants of cGMP-binding cGMP-specific phosphodiesterase. J. Biol. Chem. 273, 26982-26990. doi: 10.1074/jbc.273.41. 26982
Lee, J. W., Lee, J., and Moon, E. Y. (2014). HeLa human cervical cancer cell migration is inhibited by treatment with dibutyryl-cAMP. Anticancer Res. 34, 3447-3455.

Lee, R., Wolda, S., Moon, E., Esselstyn, J., Hertel, C., and Lerner, A. (2002). PDE7A is expressed in human B-lymphocytes and is up-regulated by elevation of intracellular cAMP. Cell Signal. 14, 277-284. doi: 10.1016/s0898-6568(01) 00250-9

Lerner, A., and Epstein, P. M. (2006). Cyclic nucleotide phosphodiesterases as targets for treatment of haematological malignancies. Biochem. J. 393, 21-41. doi: 10.1042/bj20051368

Li, L., Yee, C., and Beavo, J. A. (1999). CD3- and CD28-dependent induction of PDE7 required for T cell activation. Science 283, 848-851. doi: 10.1126/science. 283.5403.848

Lim, C. J., Han, J., Yousefi, N., Ma, Y., Amieux, P. S., Mcknight, G. S., et al. (2007). Alpha4 integrins are type I cAMP-dependent protein kinase-anchoring proteins. Nat. Cell Biol. 9, 415-421. doi: 10.1038/ncb1561

Lin, C. S., Lau, A., Tu, R., and Lue, T. F. (2000). Expression of three isoforms of cGMP-binding cGMP-specific phosphodiesterase (PDE5) in human penile cavernosum. Biochem. Biophys. Res. Commun. 268, 628-635. doi: 10.1006/bbrc. 2000.2187

Loughney, K., Hill, T. R., Florio, V. A., Uher, L., Rosman, G. J., Wolda, S. L., et al. (1998). Isolation and characterization of cDNAs encoding PDE5A, a human cGMP-binding, cGMP-specific 3',5' -cyclic nucleotide phosphodiesterase. Gene 216, 139-147. doi: 10.1016/s0378-1119(98)00303-5

Loughney, K., Martins, T. J., Harris, E. A., Sadhu, K., Hicks, J. B., Sonnenburg, W. K., et al. (1996). Isolation and characterization of cDNAs corresponding to two human calcium, calmodulin-regulated, $3^{\prime}, 5^{\prime}$-cyclic nucleotide phosphodiesterases. J. Biol. Chem. 271, 796-806. doi: 10.1074/jbc. 271.2.796

Loughney, K., Snyder, P. B., Uher, L., Rosman, G. J., Ferguson, K., and Florio, V. A. (1999). Isolation and characterization of PDE10A, a novel human 3', 5'cyclic nucleotide phosphodiesterase. Gene 234, 109-117. doi: 10.1016/s03781119(99)00171-7

Loughney, K., Taylor, J., and Florio, V. A. (2005). 3',5'-Cyclic nucleotide phosphodiesterase 11A: localization in human tissues. Int. J. Impot. Res. 17, 320-325.

Lyle, K. S., Raaijmakers, J. H., Bruinsma, W., Bos, J. L., and De Rooij, J. (2008). cAMP-induced Epac-Rap activation inhibits epithelial cell migration by modulating focal adhesion and leading edge dynamics. Cell. Signal. 20, 1104-1116.

Maganto-Garcia, E., Bu, D. X., Tarrio, M. L., Alcaide, P., Newton, G., Griffin, G. K., et al. (2011). Foxp3+-inducible regulatory T cells suppress endothelial activation and leukocyte recruitment. J. Immunol. 187, 3521-3529.

Man, H. W., Schafer, P., Wong, L. M., Patterson, R. T., Corral, L. G., Raymon, H., et al. (2009). Discovery of (S)-N-[2-[1-(3-ethoxy-4-methoxyphenyl)2-methanesulfonylethyl]-1,3-dioxo-2,3-dihy dro-1H-isoindol-4-yl] acetamide (apremilast), a potent and orally active phosphodiesterase 4 and tumor necrosis factor-alpha inhibitor. J. Med. Chem. 52, 1522-1524.

Manganiello, V. C., Smith, C. J., Degerman, E., and Belfrage, P. (1990a). "Cyclic GMP-inhibited cyclic nucleotide phosphodiesterases," in Cyclic Nucleotide Phosphodiesterases: Structure, Regulation and Drug Action, eds J. Beavo and M. D. Houslay (West Sussex: John Wiley \& Sons Ltd.), 87-115.

Manganiello, V. C., Tanaka, T., and Murashima, S. (1990b). "Cyclic GMPstimulated cyclic nucleotide phosphodiesterases," in Cyclic Nucleotide Phosphodiesterases: Structure, Regulation and Drug Action, eds J. Beavo and M. D. Houslay (West Sussex: John Wiley \& Sons Ltd.), 61-85.

Marais, R., Light, Y., Paterson, H. F., Mason, C. S., and Marshall, C. J. (1997). Differential regulation of Raf-1, A-Raf, and B-Raf by oncogenic ras and tyrosine kinases. J. Biol. Chem. 272, 4378-4383.

Martin-Alvarez, R., Paul-Fernandez, N., Palomo, V., Gil, C., Martinez, A., and Mengod, G. (2017). A preliminary investigation of phoshodiesterase 7 inhibitor VP3.15 as therapeutic agent for the treatment of experimental autoimmune encephalomyelitis mice. J. Chem. Neuroanat. 80, 27-36.

Martins, T. J., Mumby, M. C., and Beavo, J. A. (1982). Purification and characterization of a cyclic GMP-stimulated cyclic nucleotide phosphodiesterase from bovine tissues. J. Biol. Chem. 257, 1973-1979.

Maurice, D. H. (2013). PDE8A runs interference to limit PKA inhibition of Raf-1. Proc. Natl. Acad. Sci. U.S.A. 110, 6248-6249. 
Maurice, D. H., Ke, H., Ahmad, F., Wang, Y., Chung, J., and Manganiello, V. C. (2014). Advances in targeting cyclic nucleotide phosphodiesterases. Nat. Rev. Drug Discov. 13, 290-314.

Mery, P. F., Pavoine, C., Pecker, F., and Fischmeister, R. (1995). Erythro-9-(2hydroxy-3-nonyl)adenine inhibits cyclic GMP-stimulated phosphodiesterase in isolated cardiac myocytes. Mol. Pharmacol. 48, 121-130.

Michaeli, T., Bloom, T. J., Martins, T., Loughney, K., Ferguson, K., Riggs, M., et al. (1993). Isolation and characterization of a previously undetected human cAMP phosphodiesterase by complementation of cAMP phosphodiesterase-deficient Saccharomyces cerevisiae. J. Biol. Chem. 268, 12925-12932.

Michie, A. M., Lobban, M., Muller, T., Harnett, M. M., and Houslay, M. D. (1996). Rapid regulation of PDE-2 and PDE-4 cyclic AMP phosphodiesterase activity following ligation of the $\mathrm{T}$ cell antigen receptor on thymocytes: analysis using the selective inhibitors erythro-9-(2-hydroxy-3-nonyl)-adenine (EHNA) and rolipram. Cell Signal. 8, 97-110.

Milara, J., Armengot, M., Banuls, P., Tenor, H., Beume, R., Artigues, E., et al. (2012). Roflumilast N-oxide, a PDE4 inhibitor, improves cilia motility and ciliated human bronchial epithelial cells compromised by cigarette smoke in vitro. $\mathrm{Br}$. J. Pharmacol. 166, 2243-2262.

Montesano, R., Pepper, M. S., Mohle-Steinlein, U., Risau, W., Wagner, E. F., and Orci, L. (1990). Increased proteolytic activity is responsible for the aberrant morphogenetic behavior of endothelial cells expressing the middle $\mathrm{T}$ oncogene. Cell 62, 435-445.

Moon, E., Lee, R., Near, R., Weintraub, L., Wolda, S., and Lerner, A. (2002). Inhibition of PDE3B augments PDE4 inhibitor-induced apoptosis in a subset of patients with chronic lymphocytic leukemia. Clin. Cancer Res. 8, 589-595.

Mosenden, R., and Tasken, K. (2011). Cyclic AMP-mediated immune regulationoverview of mechanisms of action in T cells. Cell Signal. 23, 1009-1016.

Murata, K., Sudo, T., Kameyama, M., Fukuoka, H., Muka, M., Doki, Y., et al. (2000). Cyclic AMP specific phosphodiesterase activity and colon cancer cell motility. Clin. Exp. Metastasis 18, 599-604.

Nakata, A., Ogawa, K., Sasaki, T., Koyama, N., Wada, K., Kotera, J., et al. (2002) Potential role of phosphodiesterase 7 in human $\mathrm{T}$ cell function: comparative effects of two phosphodiesterase inhibitors. Clin. Exp. Immunol. 128, 460-466.

Netherton, S. J., and Maurice, D. H. (2005). Vascular endothelial cell cyclic nucleotide phosphodiesterases and regulated cell migration: implications in angiogenesis. Mol. Pharmacol. 67, 263-272.

Nome, T., Thomassen, G. O., Bruun, J., Ahlquist, T., Bakken, A. C., Hoff, A. M., et al. (2013). Common fusion transcripts identified in colorectal cancer cell lines by high-throughput RNA sequencing. Transl. Oncol. 6, 546-553. doi: 10.1593/tlo.13457

Norambuena, A., Metz, C., Vicuna, L., Silva, A., Pardo, E., Oyanadel, C., et al. (2009). Galectin-8 induces apoptosis in Jurkat T cells by phosphatidic acid-mediated ERK1/2 activation supported by protein kinase A downregulation. J. Biol. Chem. 284, 12670-12679. doi: 10.1074/jbc.m808949200

Nueda, A., Garcia-Roger, N., Domenech, T., Godessart, N., Cardenas, A., Santamaria-Babi, L. F., et al. (2006). Phosphodiesterase 7A1 is expressed in human CD4+ naive T cells at higher levels than in CD4+ memory cells and is not required during their CD3/CD28-dependent activation. Cell Immunol. 242, 31-38. doi: 10.1016/j.cellimm.2006.09.001

Orlowski, R. J., O’rourke, K. S., Olorenshaw, I., Hawkins, G. A., Maas, S., and Laxminarayana, D. (2008). Altered editing in cyclic nucleotide phosphodiesterase 8A1 gene transcripts of systemic lupus erythematosus $\mathrm{T}$ lymphocytes. Immunology 125, 408-419. doi: 10.1111/j.1365-2567.2008. 02850.x

Ou, Y., Zheng, X., Gao, Y., Shu, M., Leng, T., Li, Y., et al. (2014). Activation of cyclic AMP/PKA pathway inhibits bladder cancer cell invasion by targeting MAP4-dependent microtubule dynamics. Urol. Oncol. 32, 47.e21-e48.

Patrucco, E., Albergine, M. S., Santana, L. F., and Beavo, J. A. (2010). Phosphodiesterase 8A (PDE8A) regulates excitation-contraction coupling in ventricular myocytes. J. Mol. Cell Cardiol. 49, 330-333. doi: 10.1016/j.yjmcc. 2010.03.016

Peter, D., Jin, S. L., Conti, M., Hatzelmann, A., and Zitt, C. (2007). Differential expression and function of phosphodiesterase 4 (PDE4) subtypes in human primary CD4+ T cells: predominant role of PDE4D. J. Immunol. 178, 48204831. doi: 10.4049/jimmunol.178.8.4820

Pette, M., Muraro, P. A., Pette, D. F., Dinter, H., Mcfarland, H. F., and Martin, R. (1999). Differential effects of phosphodiesterase type 4-specific inhibition on human autoreactive myelin-specific T cell clones. J. Neuroimmunol. 98, 147-156.

Podzuweit, T., Nennstiel, P., and Muller, A. (1995). Isozyme selective inhibition of cGMP-stimulated cyclic nucleotide phosphodiesterases by erythro-9-(2hydroxy-3-nonyl) adenine. Cell Signal. 7, 733-738. doi: 10.1016/0898-6568(95) 00042-n

Pritchard, C. A., Hayes, L., Wojnowski, L., Zimmer, A., Marais, R. M., and Norman, J. C. (2004). B-Raf acts via the ROCKII/LIMK/cofilin pathway to maintain actin stress fibers in fibroblasts. Mol. Cell. Biol. 24, 5937-5952. doi: 10.1128/mcb.24. 13.5937-5952.2004

Pritchard, C. A., Samuels, M. L., Bosch, E., and Mcmahon, M. (1995). Conditionally oncogenic forms of the A-Raf and B-Raf protein kinases display different biological and biochemical properties in NIH 3T3 cells. Mol. Cell. Biol. 15, 6430-6442. doi: $10.1128 / \mathrm{mcb} .15 .11 .6430$

Rabe, K. F. (2011). Update on roflumilast, a phosphodiesterase 4 inhibitor for the treatment of chronic obstructive pulmonary disease. Br. J. Pharmacol. 163, 53-67. doi: 10.1111/j.1476-5381.2011.01218.x

Redondo, M., Brea, J., Perez, D. I., Soteras, I., Val, C., Perez, C., et al. (2012). Effect of phosphodiesterase 7 (PDE7) inhibitors in experimental autoimmune encephalomyelitis mice. Discovery of a new chemically diverse family of compounds. J. Med. Chem. 55, 3274-3284. doi: 10.1021/jm201720d

Sasaki, T., Kotera, J., Yuasa, K., and Omori, K. (2000). Identification of human PDE7B, a cAMP-specific phosphodiesterase. Biochem. Biophys. Res. Commun. 271, 575-583. doi: 10.1006/bbrc.2000.2661

Schafer, P. (2012). Apremilast mechanism of action and application to psoriasis and psoriatic arthritis. Biochem. Pharmacol. 83, 1583-1590. doi: 10.1016/j.bcp. 2012.01.001

Schafer, P. H., Parton, A., Gandhi, A. K., Capone, L., Adams, M., Wu, L., et al. (2010). Apremilast, a cAMP phosphodiesterase-4 inhibitor, demonstrates antiinflammatory activity in vitro and in a model of psoriasis. Br. J. Pharmacol. 159, 842-855. doi: 10.1111/j.1476-5381.2009.00559.x

Schett, G., Sloan, V. S., Stevens, R. M., and Schafer, P. (2010). Apremilast: a novel PDE4 inhibitor in the treatment of autoimmune and inflammatory diseases. Ther. Adv. Musculoskelet Dis. 2, 271-278. doi: 10.1177/1759720x10381432

Schett, G., Wollenhaupt, J., Papp, K., Joos, R., Rodrigues, J. F., Vessey, A. R., et al. (2012). Oral apremilast in the treatment of active psoriatic arthritis: results of a multicenter, randomized, double-blind, placebo-controlled study. Arthritis Rheum. 64, 3156-3167. doi: 10.1002/art.34627

Sharma, R. K., and Hickie, R. A. (1996). "Ca2+/calmodulin-dependent cyclic nucleotide phosphodiesterase (PDE1)," in Phosphodiesterase Inhibitors, eds C. Schudt, G. Dent, and K. F. Rabe (London: Academic Press), 65-80. doi: 10.1016/ b978-012210720-7/50006-x

Sheth, S. B., Chaganti, K., Bastepe, M., Ajuria, J., Brennan, K., Biradavolu, R. et al. (1997). Cyclic AMP phosphodiesterases in human lymphocytes. Br. J. Haematol. 99, 784-789. doi: 10.1046/j.1365-2141.1997.4803282.x

Shimizu-Albergine, M., Van Yserloo, B., Golkowski, M. G., Ong, S. E., Beavo, J. A., and Bornfeldt, K. E. (2016). SCAP/SREBP pathway is required for the full steroidogenic response to cyclic AMP. Proc. Natl. Acad. Sci. U.S.A. 113, E5685-E5693.

Sloka, S., Metz, L. M., Hader, W., Starreveld, Y., and Yong, V. W. (2013). Reduction of microglial activity in a model of multiple sclerosis by dipyridamole. J. Neuroinflammation 10:89.

Soderling, S. H., Bayuga, S. J., and Beavo, J. A. (1998a). Cloning and characterization of a CAMP-specific cyclic nucleotide phosphodiesterase. Proc. Natl. Acad. Sci. U.S.A. 95, 8991-8996. doi: 10.1073/pnas.95.15.8991

Soderling, S. H., Bayuga, S. J., and Beavo, J. A. (1998b). Identification and characterization of a novel family of cyclic nucleotide phosphodiesterases. J. Biol. Chem. 273, 15553-15558. doi: 10.1074/jbc.273.25.15553

Soderling, S. H., Bayuga, S. J., and Beavo, J. A. (1999). Isolation and characterization of a dual-substrate phosphodiesterase gene family: PDE10A. Proc. Natl. Acad. Sci. U.S.A. 96, 7071-7076. doi: 10.1073/pnas.96.12.7071

Soderling, S. H., and Beavo, J. A. (2000). Regulation of cAMP and cGMP signaling: new phosphodiesterases and new functions. Curr. Opin. Cell. Biol. 12, 174-179. doi: 10.1016/s0955-0674(99)00073-3

Sommer, N., Martin, R., Mcfarland, H. F., Quigley, L., Cannella, B., Raine, C. S., et al. (1997). Therapeutic potential of phosphodiesterase type 4 inhibition in chronic autoimmune demyelinating disease. J. Neuroimmunol. 79, 54-61. doi: 10.1016/s0165-5728(97)00111-2 
Spano, D., Marshall, J. C., Marino, N., De Martino, D., Romano, A., Scoppettuolo, M. N., et al. (2013). Dipyridamole prevents triple-negative breast-cancer progression. Clin. Exp. Metastasis 30, 47-68. doi: 10.1007/s10585-012-9506-0

Sriram, K., and Insel, P. A. (2018). G protein-coupled receptors as targets for approved drugs: how many targets and how many drugs? Mol. Pharmacol. 93, 251-258. doi: $10.1124 / \mathrm{mol} .117 .111062$

Steinman, L. (2005). Blocking adhesion molecules as therapy for multiple sclerosis: natalizumab. Nat. Rev. Drug Discov. 4, 510-518. doi: 10.1038/nrd1752

Szczypka, M. (2020). Role of phosphodiesterase 7 (PDE7) in T cell activity. effects of selective PDE7 inhibitors and dual PDE4/7 inhibitors on T cell functions. Int. J. Mol. Sci. 21:6118. doi: 10.3390/ijms21176118

Takeuchi, M., and Baichwal, V. R. (1995). Induction of the gene encoding mucosal vascular addressin cell adhesion molecule 1 by tumor necrosis factor alpha is mediated by NF-kappa B proteins. Proc. Natl. Acad. Sci. U.S.A. 92, 3561-3565. doi: 10.1073/pnas.92.8.3561

Taylor, K. E., Wong, Q., Levine, D. M., Mchugh, C., Laurie, C., Doheny, K., et al. (2017). Genome-wide association analysis reveals genetic heterogeneity of sjogren's syndrome according to ancestry. Arthritis Rheumatol. 69, 1294-1305. doi: $10.1002 /$ art. 40040

Tenor, H., Hatzelmann, A., Beume, R., Lahu, G., Zech, K., and Bethke, T. D. (2011). Pharmacology, clinical efficacy, and tolerability of phosphodiesterase4 inhibitors: impact of human pharmacokinetics. Handb. Exp. Pharmacol. 204, 85-119. doi: 10.1007/978-3-642-17969-3_3

Tenor, H., Staniciu, L., Schudt, C., Hatzelmann, A., Wendel, A., Djukanovic, R., et al. (1995). Cyclic nucleotide phosphodiesterases from purified human CD4+ and CD8+ T lymphocytes. Clin. Exp. Allergy 25, 616-624. doi: 10.1111/j.13652222.1995.tb01109.x

Tom, W. L., Van Syoc, M., Chanda, S., and Zane, L. T. (2016). Pharmacokinetic profile, safety, and tolerability of crisaborole topical ointment, $2 \%$ in adolescents with atopic dermatitis: an open-label phase 2a study. Pediatr. Dermatol. 33, 150-159. doi: 10.1111/pde.12780

Tsai, L. C., and Beavo, J. A. (2012). Regulation of adrenal steroidogenesis by the high-affinity phosphodiesterase 8 family. Horm. Metab. Res. 44, 790-794. doi: 10.1055/s-0032-1321861

Tsai, L. C., Chan, G. C., Nangle, S. N., Shimizu-Albergine, M., Jones, G. L., Storm, D. R., et al. (2012). Inactivation of Pde8b enhances memory, motor performance, and protects against age-induced motor coordination decay. Genes Brain Behav. 11, 837-847. doi: 10.1111/j.1601-183x.2012.00836.x

Tsai, L. C., Shimizu-Albergine, M., and Beavo, J. A. (2010). The high affinity cAMPspecific phosphodiesterase $8 \mathrm{~B}$ (PDE8B) controls steroidogenesis in the mouse adrenal gland. Mol. Pharmacol. 79, 639-648. doi: 10.1124/mol.110.069104

Vaeth, M., Gogishvili, T., Bopp, T., Klein, M., Berberich-Siebelt, F., Gattenloehner, S., et al. (2011). Regulatory $\mathrm{T}$ cells facilitate the nuclear accumulation of inducible cAMP early repressor (ICER) and suppress nuclear factor of activated T cell c1 (NFATc1). Proc. Natl. Acad. Sci. U.S.A. 108, 2480-2485. doi: 10.1073/ pnas. 1009463108

Vang, A. G., Basole, C., Dong, H., Nguyen, R. K., Housley, W., Guernsey, L., et al. (2016). Differential expression and function of PDE8 and PDE4 in effector T cells: implications for PDE8 as a drug target in inflammation. Front. Pharmacol. $7: 259$.

Vang, A. G., Ben-Sasson, S. Z., Dong, H., Kream, B., Deninno, M. P., Claffey, M. M., et al. (2010). PDE8 regulates rapid Teff cell adhesion and proliferation independent of ICER. PLoS One 5:e12011. doi: 10.1371/journal.pone.0012011

Vang, A. G., Housley, W., Dong, H., Basole, C., Ben-Sasson, S. Z., Kream, B. E., et al. (2013). Regulatory T-cells and cAMP suppress effector T-cells independently of PKA-CREM/ICER: a potential role for Epac. Biochem. J. 456, 463-473. doi: 10.1042/bj20130064

Victoni, T., Gleonnec, F., Lanzetti, M., Tenor, H., Valenca, S., Porto, L. C., et al. (2014). Roflumilast N-oxide prevents cytokine secretion induced by cigarette smoke combined with LPS through JAK/STAT and ERK1/2 inhibition in airway epithelial cells. PLoS One 9:e85243. doi: 10.1371/journal.pone.0085243

Virgilio, A., Spano, D., Esposito, V., Di Dato, V., Citarella, G., Marino, N., et al. (2012). Novel pyrimidopyrimidine derivatives for inhibition of cellular proliferation and motility induced by h-prune in breast cancer. Eur. J. Med. Chem. 57, 41-50. doi: 10.1016/j.ejmech.2012.08.020

Wallace, D. A., Johnston, L. A., Huston, E., Macmaster, D., Houslay, T. M., Cheung, Y. F., et al. (2005). Identification and characterization of PDE4A11, a novel, widely expressed long isoform encoded by the human PDE4A cAMP phosphodiesterase gene. Mol. Pharmacol. 67, 1920-1934.

Wang, C., Lin, W., Playa, H., Sun, S., Cameron, K., and Buolamwini, J. K. (2013a). Dipyridamole analogs as pharmacological inhibitors of equilibrative nucleoside transporters. Identification of novel potent and selective inhibitors of the adenosine transporter function of human equilibrative nucleoside transporter 4 (hENT4). Biochem. Pharmacol. 86, 1531-1540.

Wang, C., Schwab, L. P., Fan, M., Seagroves, T. N., and Buolamwini, J. K. (2013b). Chemoprevention activity of dipyridamole in the MMTV-PyMT transgenic mouse model of breast cancer. Cancer Prev. Res. (Phila) 6, 437-447.

Wang, H., Yan, Z., Yang, S., Cai, J., Robinson, H., and Ke, H. (2008). Kinetic and structural studies of phosphodiesterase-8A and implication on the inhibitor selectivity. Biochemistry 47, 12760-12768.

Wang, J. H., Sharma, R. K., and Mooibroek, M. J. (1990). "Calmodulin-stimulated cyclic nucleotide phosphodiesterases," in Cyclic Nucleotide Phosphodiesterases: Structure, Regulation and Drug Action, eds J. Beavo and M. D. Houslay (West Sussex: John Wiley \& Sons Ltd), 19-59.

Wang, P., Wu, P., Egan, R. W., and Billah, M. M. (2000). Cloning, characterization, and tissue distribution of mouse phosphodiesterase 7A1. Biochem. Biophys. Res. Commun. 276, 1271-1277.

Wang, P., Wu, P., Egan, R. W., and Billah, M. M. (2003). Identification and characterization of a new human type 9 cGMP-specific phosphodiesterase splice variant (PDE9A5). Differential tissue distribution and subcellular localization of PDE9A variants. Gene 314, 15-27.

Wang, P., Wu, P., Myers, J. G., Stamford, A., Egan, R. W., and Billah, M. M. (2001). Characterization of human, dog and rabbit corpus cavernosum type 5 phosphodiesterases. Life Sci. 68, 1977-1987.

Wang, T., Sheppard, J. R., and Foker, J. E. (1978). Rise and fall of cyclic AMP required for onset of lymphocyte DNA synthesis. Science 201, 155-157.

Weber, C. K., Slupsky, J. R., Herrmann, C., Schuler, M., Rapp, U. R., and Block, C. (2000). Mitogenic signaling of Ras is regulated by differential interaction with Raf isozymes. Oncogene 19, 169-176.

Weeks, J. L., Zoraghi, R., Beasley, A., Sekhar, K. R., Francis, S. H., and Corbin, J. D. (2005). High biochemical selectivity of tadalafil, sildenafil and vardenafil for human phosphodiesterase 5A1 (PDE5) over PDE11A4 suggests the absence of PDE11A4 cross-reaction in patients. Int. J. Impot. Res. 17, 5-9.

Wehbi, V. L., and Tasken, K. (2016). Molecular mechanisms for cAMP-mediated immunoregulation in T cells-role of anchored protein kinase A signaling units. Front. Immunol. 7:222.

Weis, W. I., and Kobilka, B. K. (2018). The molecular basis of G protein-coupled receptor activation. Annu. Rev. Biochem. 87, 897-919.

Wittmann, M., and Helliwell, P. S. (2013). Phosphodiesterase 4 inhibition in the treatment of psoriasis, psoriatic arthritis and other chronic inflammatory diseases. Dermatol. Ther. (Heidelb) 3, 1-15.

Wojnowski, L., Stancato, L. F., Larner, A. C., Rapp, U. R., and Zimmer, A. (2000). Overlapping and specific functions of Braf and Craf-1 proto-oncogenes during mouse embryogenesis. Mech. Dev. 91, 97-104.

Xu, C., Wyman, A. R., Alaamery, M. A., Argueta, S. A., Ivey, F. D., Meyers, J. A., et al. (2016). Anti-inflammatory effects of novel barbituric acid derivatives in $\mathrm{T}$ lymphocytes. Int. Immunopharmacol. 38, 223-232.

Yan, C., Zhao, A. Z., Bentley, J. K., Loughney, K., Ferguson, K., and Beavo, J. A. (1995). Molecular cloning and characterization of a calmodulin-dependent phosphodiesterase enriched in olfactory sensory neurons. Proc. Natl. Acad. Sci. U.S.A. 92, 9677-9681.

Yang, G., Mcintyre, K. W., Townsend, R. M., Shen, H. H., Pitts, W. J., Dodd, J. H., et al. (2003). Phosphodiesterase 7A-deficient mice have functional T cells. J. Immunol. 171, 6414-6420.

Yednock, T. A., Cannon, C., Fritz, L. C., Sanchez-Madrid, F., Steinman, L., and Karin, N. (1992). Prevention of experimental autoimmune encephalomyelitis by antibodies against alpha 4 beta 1 integrin. Nature 356, 63-66.

Yu, J., Wolda, S. L., Frazier, A. L., Florio, V. A., Martins, T. J., Snyder, P. B., et al. (1997). Identification and characterisation of a human calmodulin-stimulated phosphodiesterase PDE1B1. Cell Signal. 9, 519-529.

Yuasa, K., Kotera, J., Fujishige, K., Michibata, H., Sasaki, T., and Omori, K. (2000). Isolation and characterization of two novel phosphodiesterase PDE11A variants showing unique structure and tissue-specific expression. J. Biol. Chem. 275, 31469-31479. 
Zane, L. T., Chanda, S., Jarnagin, K., Nelson, D. B., Spelman, L., and Gold, L. S. (2016a). Crisaborole and its potential role in treating atopic dermatitis: overview of early clinical studies. Immunotherapy 8, 853-866.

Zane, L. T., Kircik, L., Call, R., Tschen, E., Draelos, Z. D., Chanda, S., et al. (2016b). Crisaborole topical ointment, $2 \%$ in patients ages 2 to 17 years with atopic dermatitis: A phase 1b, Open-Label, maximal-use systemic exposure study. Pediatr. Dermatol. 33, 380-387.

Zhao, A. Z., Yan, C., Sonnenburg, W. K., and Beavo, J. A. (1997). Recent advances in the study of $\mathrm{Ca} 2+/ \mathrm{CaM}$-activated phosphodiesterases: expression and physiological functions. Adv. Second Messenger Phosphoprotein Res. 31, 237-251.

Zimmerman, N. P., Roy, I., Hauser, A. D., Wilson, J. M., Williams, C. L., and Dwinell, M. B. (2015). Cyclic AMP regulates the migration and invasion potential of human pancreatic cancer cells. Mol. Carcinog. 54, 203-215.

Conflict of Interest: The authors declare that the research was conducted in the absence of any commercial or financial relationships that could be construed as a potential conflict of interest.

Copyright (c) 2021 Epstein, Basole and Brocke. This is an open-access article distributed under the terms of the Creative Commons Attribution License (CC BY). The use, distribution or reproduction in other forums is permitted, provided the original author(s) and the copyright owner(s) are credited and that the original publication in this journal is cited, in accordance with accepted academic practice. No use, distribution or reproduction is permitted which does not comply with these terms. 